\title{
The Stream Biome Gradient Concept: factors controlling lotic systems across broad biogeographic scales
}

\author{
Walter K. Dodds ${ }^{1,5}$, Keith Gido ${ }^{1,6}$, Matt R. Whiles ${ }^{2,7}$, Melinda D. Daniels ${ }^{3,8}$, \\ and Bartosz P. Grudzinski ${ }^{4,9}$ \\ ${ }^{1}$ Department of Biology, Kansas State University, Manhattan, Kansas 66506 USA \\ ${ }^{2}$ Department of Zoology, Southern Illinois University, Carbondale, Illinois 62901 USA \\ ${ }^{3}$ Stroud Water Research Center, 970 Spencer Road, Avondale, Pennsylvania 19311 USA \\ ${ }^{4}$ Department of Geography, Kansas State University, Manhattan, Kansas 66506 USA
}

\begin{abstract}
We propose the Stream Biome Gradient Concept as a way to predict macroscale biological patterns in streams. This concept is based on the hypothesis that many abiotic and biotic features of streams change predictably along climate (temperature and precipitation) gradients because of direct influences of climate on hydrology, geomorphology, and interactions mediated by terrestrial vegetation. The Stream Biome Gradient Concept generates testable hypotheses related to continental variation among streams worldwide and allows aquatic scientists to understand how results from one biome might apply to a less-studied biome. Some predicted factors change monotonically across the biome/climate gradients, whereas others have maxima or minima in the central portion of the gradient. For example, predictions across the gradient from drier deserts through grasslands to wetter forests include more permanent flow, less bare ground, lower erosion and sediment transport rates, decreased importance of autochthonous $C$ inputs to food webs, and greater stream animal species richness. In contrast, effects of large ungulate grazers on streams are expected to be greater in grasslands than in forests or deserts, and fire is expected to have weaker effects in grassland streams than in desert and forest streams along biome gradients with changing precipitation and constant latitude or elevation. Understanding historic patterns among biomes can help describe the evolutionary template at relevant biogeographic scales, can be used to broaden other conceptual models of stream ecology, and could lead to better management and conservation across the broadest scales.
\end{abstract}

Key words: stream, biome, lotic, macro-scale, macrosystems, biogeography

Stream ecologists have devised several ecological concepts to understand streams at broad spatial or temporal scales. Transitional characteristics of stream ecosystems across a gradient from headwaters to large rivers were linked in the River Continuum Concept (RCC; Vannote et al. 1980). This concept centered on forested streams, but the authors also considered that different biomes could fit into the concept with some modification. Other synthetic approaches to stream and river ecology, e.g., the Flood-Pulse concept (Junk et al. 1989) and the Riverine Ecosystem Synthesis (Thorp et al. 2006), consider terrestrial influences, but not with primary emphasis on the biomes in which the rivers or streams are embedded.

Very large-scale approaches (e.g., whole large river basins, continents, cross-biome) are important for many key ecological issues (Heffernan et al. 2014), including nutrient criteria and nutrient ecoregions (Omernik 1987) and geographic patterns of animal communities across freshwater ecoregions (Abell et al. 2008). Species distributions and state and national jurisdictions occur across very large scales that often include multiple biomes. Some attention has been paid to how river networks might vary across broad scales (e.g., McCluney et al. 2014), but we are not aware of a specific framework that considers how streams vary predictably across the broadest scales among different biomes. Our research on multiple stream biomes has led us to view gradients across multiple biomes as having the potential to predict differences in general stream community and ecosystem characteristics at the broadest scales.

Control of plant communities by climatic (temperature and precipitation) gradients has been recognized for $>65 \mathrm{y}$

E-mail addresses: ${ }^{5}$ wkdodds@ksu.edu; ${ }^{6}$ kgido@ksu.edu; ${ }^{7}$ mwhiles@zoology.siu.edu; ${ }^{8}$ mdaniels@stroudcenter.org; ${ }^{9}$ gobhawks@ksu.edu

DOI: 10.1086/679756. Received 22 April 2014; Accepted 30 October 2014; Published online 20 January 2015.

Freshwater Science. 2015. 34(1):1-19. ๑ 2015 by The Society for Freshwater Science. 
and forms the basis of the biome concept (Holdridge 1947). We extended the biome concept to investigate how gradients of precipitation and temperature can predictably control differences in stream hydrology and geomorphology directly or as a consequence of interactions of streams with the terrestrial biomes that dominate under specific climatic conditions. We further explored how interbiome differences can constrain the structure and function of stream communities and ecosystems.

Holdridge (1947) showed how interactions between temperature (as influenced by latitude or elevation) and precipitation could be used to predict the functional groups of vegetation found in terrestrial environments, and this approach was adopted by others, e.g., in the biome continuum concept of McIntosh (1967). We extended this view to propose the Stream Biome Gradient Concept. This concept is based on the hypothesis that streams change predictably along climate (temperature and precipitation) gradients because of direct influences of climate on hydrology and geomorphology and indirect influences mediated by terrestrial vegetation. We use this concept to predict stream abiotic and biotic characteristics (e.g., hydrology, geomorphology, water quality, ecosystem metabolism, and animal diversity and function) across broad climate gradients (Fig. 1). We developed this idea as we tried to understand and describe grassland streams in relation to other stream types on which we have worked (e.g., deserts, tropical rain forest, deciduous, and evergreen temperate forests).

Precipitation gradients across continental land masses, which often are related to rain shadows or other climatic transitions (e.g., position of major atmospheric convection cells), are common in many parts of the world and lead to gradients from deserts to forests. These patterns can span continents or occur over relatively short distances in mountainous areas. Coupled with these patterns, temperature gradients associated with elevation or latitude influence vegetative characteristics and hydrology. These climate patterns can lead to gradients from warm tropical lowlands to arctic tundra, or over shorter distances from tropical lowland to tundra on high tropical mountains. We asked whether stream properties change continuously across large-scale biome gradients, are invariant, or have unique attributes dictated by the biomes in which they occur that do not scale linearly with climate gradients (e.g., nonmonotonic patterns across gradients). Freshwater biomes (ecoregions) have been assigned unique status as ecoregions based on vertebrate inhabitants (Abell et al. 2008), but the relationships of these ecoregion designations to other stream properties and to terrestrial biomes at continental scales are not clear.

Streams are the dominant interface between terrestrial and aquatic ecosystems (Hynes 1975). They transport and transform (Mulholland et al. 2008) materials from land to the ocean and ultimately determine coastal marine productivity. Streams and rivers also are important sources of greenhouse gasses (Beaulieu et al. 2011, Raymond et al. 2013), but we do not know how these functions are distributed globally and relate to biomes.

The direct link between terrestrial and lotic ecosystems is runoff. Temperate forests produce $30 \%$ of global runoff.

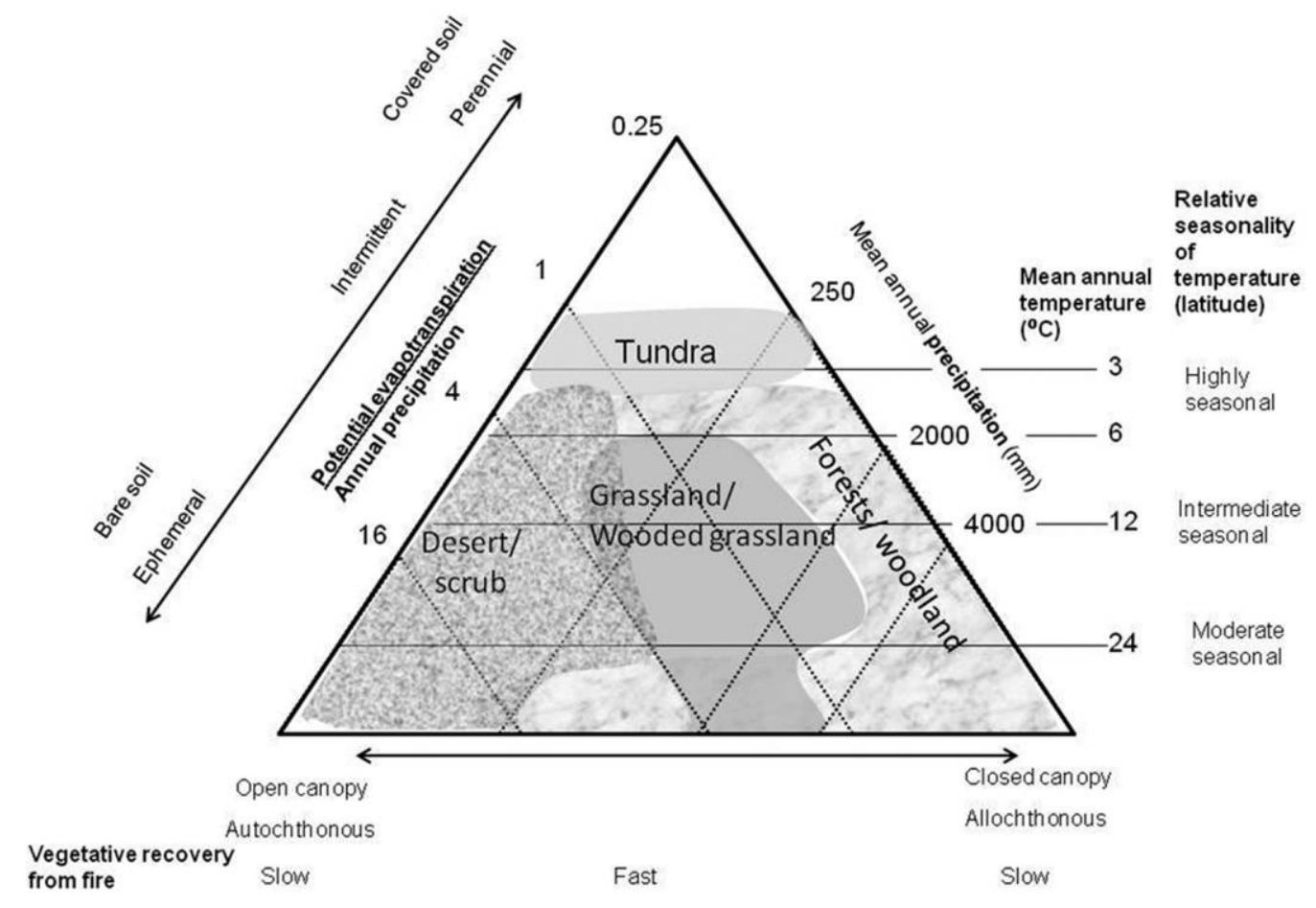

Figure 1. Climate zones, vegetation types, and relationship to stream characteristics (modified from Holdridge 1947). 
In contrast, tropical and subtropical evergreen forests produce $\sim 50 \%$, and grasslands and savannas the remaining $20 \%$, of runoff. Deserts contribute very little runoff, though they constitute a substantial area (Table 1). Streams in temperate forests appear to be the most studied. We analyzed ISI Web of Science ${ }^{\circledR}$ (Thomson Reuters, Philadelphia, Pennsylvania) citation records (January 2013) by searching for papers in the area of "ecology" with the terms "river" or "stream" in them. Within these results, most citations included the term "forest" (8609) followed by "tropic" (594; " is a wild-card search term), "rain forest" (156), "arctic" (153), "grassland” (166), "prairie” (77), or "tundra" (46). This approach is a coarse way to evaluate the literature, but it does support the idea that knowledge of stream ecology is strongly influenced by research from forested streams. Streams types are not studied proportionately to their global occurrence, so we propose that general patterns linked to factors that vary across biome types could guide stream research and help extend results from commonly studied stream types to other, less-studied systems.

Here, we characterize streams across large-scale biome gradients with respect to characteristics that define some major aspects of their lotic ecology and biogeochemical and geomorphologic role in the landscape: 1) climatic gradients and links between biomes and hydrology, 2) geomorphology across large-scale biome gradients, 3) ecosys- tem properties, including water quality, nutrient dynamics, and metabolism, as they vary with biome, 4) variation in animal community diversity and dynamics, and 5) linkages with other integrative ideas on lotic ecology. We caution that we are addressing very broad biogeographic patterns. These generalizations are not meant to apply to smaller scales (e.g., strong rain shadows and elevation gradients on islands), although some of the concepts given here may well transfer to some aspects of smaller-scale gradients. Many of the topics discussed herein are not yet well studied in all systems, so we were able to make predictions and hypothesize based only on limited published information or broad, well established biological and physical principles.

\section{CLIMATE GRADIENTS AND LINKS BETWEEN BIOMES AND HYDROLOGY Climate and biome gradients}

Temperature and precipitation as factors controlling broad patterns of the biomes of terrestrial ecosystems can be adapted to understand stream communities and ecosystems because many of the same factors that control terrestrial plant communities also control runoff (Tables 1, 2). Gradients of terrestrial biomes are driven by precipitation and temperature as related to the relationship between potential evapotranspiration (PET) and actual evapo-

Table 1. Percent land area, mean (SD) annual temperature, precipitation, runoff, and percentage of global runoff for global biomes. Area and runoff data are classified by the ecoregional boundary data set (http://conserveonline.org/workspaces/ecoregional.shapefile). Precipitation, temperature, and runoff data are from Hijmans et al. (2005).

\begin{tabular}{|c|c|c|c|c|c|}
\hline Biome & $\begin{array}{l}\text { Land area } \\
\text { (\%) }\end{array}$ & $\begin{array}{c}\text { Temperature } \\
\left({ }^{\circ} \mathrm{C}\right)\end{array}$ & $\begin{array}{l}\text { Precipitation } \\
\quad(\mathrm{mm})\end{array}$ & $\begin{array}{l}\text { Runoff } \\
(\mathrm{mm})\end{array}$ & $\begin{array}{c}\text { Runoff } \\
(\%)\end{array}$ \\
\hline Tropical/Subtropical Grassland, Savannah, and Shrub (TGS) & 19 & $24.7(3.0)$ & $933(506)$ & $204(274)$ & 12 \\
\hline Temperate Grassland, Savannah, and Shrub (TeGS) & 10 & $7.9(6.5)$ & $448(215)$ & $92(122)$ & 3 \\
\hline Montane Grass and Shrub (MGS) & 4 & $3.8(8.7)$ & $461(430)$ & $283(433)$ & 3 \\
\hline Flooded Grass and Savannah (FGS) & & $20.6(8.8)$ & $766(424)$ & $87(177)$ & \\
\hline Mediterranean Forests and Scrub (MFS) & & $15.4(2.9)$ & $488(254)$ & $152(196)$ & \\
\hline Deserts and Xeric Shrub (DXS) & & $19.7(7.3)$ & $177(192)$ & $31(109)$ & \\
\hline Deserts + Mediterranean (DM) & 10 & & & & 2 \\
\hline Tropical/Subtropical Coniferous Forests (TCF) & & $18.2(4.1)$ & $1218(598)$ & $370(432)$ & \\
\hline Tropical/Subtropical Moist Broadleaf Forests (TMBF) & & $23.9(3.5)$ & $2051(778)$ & $831(695)$ & \\
\hline Tropical/Subtropical Moist Forests (TMF) & 16 & & & & 44 \\
\hline Tropical/Subtropical Dry Broadleaf Forests (TDBF) & 3 & $24.5(2.9)$ & $1084(478)$ & $331(291)$ & 3 \\
\hline Temperate Broadleaf and Mixed Forests (TeBF) & 12 & $9.0(4.8)$ & $874(438)$ & $289(270)$ & 11 \\
\hline Temperate Conifer Forests (TeCS) & & $5.2(7.3)$ & $842(517)$ & $341(384)$ & \\
\hline Boreal Forests/Taiga (BFT) & & $-4.5(4.9)$ & $514(207)$ & $243(149)$ & \\
\hline Conifer + Boreal Forests (CBF) & 24 & & & & 20 \\
\hline Tundra $(\mathrm{T})$ & & $-11.3(5.1)$ & $349(241)$ & $247(247)$ & \\
\hline Rock and Ice (RI) & & $-16.4(5.8)$ & $853(460)$ & $776(723)$ & \\
\hline Tundra + Rock and Ice (TRI) & 2 & & & & 2 \\
\hline
\end{tabular}


transpiration (AET; Fig. 1). In a general sense, forests dominate where AET is equal or close to PET, grasslands where AET is seasonally less than PET, and deserts where AET is almost always lower than PET. In areas where adequate moisture is present for tree growth, grasslands can still occur where periodic fires and livestock grazing (or other factors) remove trees (Staver et al. 2011). Prentice et al. (1992) suggested that the minimum tolerated annual moisture availability is lower for grasses and dryland shrubs than trees. They also predicted that woodlands, tropical dry forests and savannas, cool grass and shrub lands, warm grass/shrub, and deserts occur where $>65 \%, 45$ to $80 \%, 28$ to $65 \%, 18$ to $28 \%$, and $<18 \%$ of moisture demand is met, respectively. In grasslands and deserts, surface runoff is severely limited, at least seasonally, compared to in forests. Of course, generalization has its limits, and substantial variation can exist within classifications of terrestrial biomes. Thus, forests can occur under conditions ranging from almost desert to rainforest, and grasslands can occur in deserts and in conditions with soils saturated for most of the year (e.g., grass-dominated wetlands).

Observations of relationships among global terrestrial vegetative cover and hydrologic characteristics are consistent with global distribution patterns noted by Dodds (1997) and updated here (Table 1). Water yield (net runoff) of grasslands $(\sim 50 \mathrm{~mm} / \mathrm{y})$, while greater than that of deserts, is substantially lower than that of forests $(\sim 400$ $\mathrm{mm} / \mathrm{y}$ ), and most forests yield $\geq 300 \mathrm{~mm}$ of runoff. Tundra areas are generally characterized by lower runoff (Table 1).
Latitudinal or elevational variation also can influence water relations and vegetative dominance. Trees cannot establish in areas with extended cold, such as high-latitude or high-elevation tundra. Thus, shrubs and grasses dominate tundra. At high latitudes or elevations, low temperatures can limit $\mathrm{AET}$, and most precipitation is lost to runoff. High-latitude areas are highly seasonal, dominated by permafrost, and most surface water is frozen for much of the year, except for deep rivers and lakes. Thus, runoff is predictably seasonal in such habitats. High-elevation habitats can resemble high-latitude habitats with respect to vegetation and runoff patterns, but very high-elevation habitats in tropical areas can range from highly seasonal to relatively constant, making generalizations on hydrology difficult (Ponette-González et al. 2014).

\section{Hydrology and biome gradients}

Desert and drier grassland streams are generally intermittent or ephemeral, except in areas with permanent groundwater flow or where fed by runoff from other biomes (e.g., mountainous snowmelt-dominated headwaters; Table 2). We define intermittent as usually drying at $\geq 1$ times/y and ephemeral as not holding surface water in most of the channel for most of the year (Dodds and Whiles 2010). Although not strictly intermittent, streams in high latitude or altitude areas also flow for only part of the year because they may freeze completely and could be considered functionally intermittent. Drying can include complete desiccation, or in less severe cases, disconnection of large pools by dry shallower areas. Intermittent and

Table 2. Predicted abiotic characteristics of streams across biomes and with human modification of the landscape at global scales. Hydrology data are from Olden and Poff (2003).

\begin{tabular}{|c|c|c|c|c|c|c|}
\hline Stream type & $\begin{array}{l}\text { Drainage } \\
\text { density }\end{array}$ & $\begin{array}{l}\text { Characteristic } \\
\text { hydrology }\end{array}$ & $\begin{array}{c}\text { Daily } \\
\text { temperature } \\
\text { extremes }\end{array}$ & $\begin{array}{c}\text { Seasonal } \\
\text { temperature } \\
\text { extremes }\end{array}$ & $\begin{array}{l}\text { Light in } \\
\text { low order } \\
\text { streams }\end{array}$ & Nutrients \\
\hline Temperate grassland & $\begin{array}{l}\text { Low- } \\
\text { medium }\end{array}$ & $\begin{array}{l}\text { Harsh intermittent, } \\
\text { intermittent } \\
\text { flashy, or runoff }\end{array}$ & High & High & $\begin{array}{l}\text { Open or } \\
\text { closed }\end{array}$ & Low \\
\hline Tropical grassland & High & $\begin{array}{l}\text { Harsh intermittent, } \\
\text { intermittent } \\
\text { flashy, or runoff }\end{array}$ & High & Low & $\begin{array}{l}\text { Open or } \\
\text { closed }\end{array}$ & Low \\
\hline Tropical evergreen forest & High & Stable groundwater & Low & Low & Closed & Low \\
\hline $\begin{array}{l}\text { Tropical and temperate } \\
\text { seasonal deciduous forest }\end{array}$ & Medium & $\begin{array}{l}\text { Perennial flashy } \\
\text { or runoff }\end{array}$ & Low & Medium & $\begin{array}{l}\text { Seasonally } \\
\text { open }\end{array}$ & Low \\
\hline Alpine/tundra & High & Snowmelt & High & High & Open & Low \\
\hline Temperate evergreen & Medium & Snowmelt & Low & High & Closed & Low \\
\hline Desert & Low & Harsh intermittent & High & High & Open & Medium \\
\hline Urban & Variable & $\begin{array}{l}\text { Generally more } \\
\text { flashy than native }\end{array}$ & Variable & $\begin{array}{l}\text { Variable, } \\
\text { usually warmer }\end{array}$ & $\begin{array}{l}\text { Variable, } \\
\text { often open }\end{array}$ & High \\
\hline Cropland & Variable & Variable & High & Variable & Often open & High \\
\hline
\end{tabular}


ephemeral streams in arid and semi-arid regions can be very important as local sources of water for organisms within (e.g., opportunistic aquatic organisms) and outside of (e.g., wildlife and livestock) the stream, and can be biogeochemical hot spots during wet periods (Lake 2003). The climatic factors that lead to intermittency are linked to factors that cause dominance of grasses or bare soil in a watershed (Fig. 1), and can be related to many aspects of stream ecology (Table 3).

We expect hydrologic gradients to follow precipitation gradients, such that: 1) intermittent or ephemeral reaches are more common and more extensive in small grassland streams and deserts than in forests (i.e., intermittent reaches are longer and occur further down into the watershed making up a greater proportion of the drainage network), 2) hydrologic extremes are more frequent and intense (flooding and drying) in deserts and mesic grasslands than in forested areas, and 3) drainage density (the total length of rivers and streams in a basin divided by the area of the basin) is lowest in deserts, intermediate in grasslands, and greatest in forests (Table 3).

Latitudinal temperature gradients confound these predictions in that high-latitude areas can have high drainage density even with limited runoff because AET rates are relatively low, and even modest amounts of precipitation must runoff over fairly short periods of time and will not be lost to the subsurface (permafrost does not allow infiltration). Altitudinal temperature gradients also confound these predictions because the gradient from tundra to other systems happens within very short distances.

We also expect per capita human influences on river and stream hydrology to vary across gradients spanning different biomes because human influences across biomes are substantial (Fig. 2). In forested areas, water is abundant, so abstraction from larger rivers should have the weakest effects, but landuse change and channel alteration may be common in the smallest streams. Given the seasonal nature of precipitation or generally low annual precipitation in most grasslands, grassland streams and rivers are very likely to be appropriated for human uses either through use of surface water and damming or through abstraction of ground water. In deserts, humans and livestock are concentrated around the few permanent water sources, so perennial waters are heavily affected. The smallest desert streams rarely flow (except in urban areas where people might actually cause them to flow by watering), so they are modestly impacted except through water withdrawal from aquifers. Most large rivers are heavily dammed and experience water extraction, especially in arid climate regions.

Human influences also follow latitudinal or elevation gradients. High population density is rare at high latitudes and greatest in the tropics of the northern hemisphere, and human population density is greatest at low altitudes globally (Cohen and Small 1998). Thus, we expect temperature gradients to interact with how much human impact occurs on hydrology, although population density in the northern hemisphere temperate zone is almost as high as in the tropics.

In general, large-scale analyses of hydrology across continents and biome gradients are only just beginning. Poff et al. (2006a) provided a template for hierarchical classification across parts of several continents and detailed examples from 5 North American basins. Many parts of the world currently have too few stream gages to be analyzed in this fashion, but the approach used by Poff et al. (2006a) could be used to link gradients across biomes as discussed here to more detailed flow characteristics of rivers and streams across those biomes.

Considerable variation in hydrology can occur within broad biome types. Here, we provide a detailed example from grasslands that occurred historically across a gradient where seasonal precipitation is less than PET in the drier areas and greater than PET in the wetter areas. This example illustrates how spatial heterogeneity within a biome can lead to resemblance between streams on the opposite ends of the extremes that generally define biome boundaries. Other biome types also can occur across climate gradients (e.g., dry-to-wet forests, dry-to-wet tundra), but we discuss only grasslands here.

Grassland streams in dry-to-moderately-wet areas are characterized by intermittent flashy or harsh flow regimes (Olden and Poff 2003), as would be expected in other grassland areas with monsoonal rainfall patterns (e.g., the Brazilian Cerrado; Wantzen 2003), mid-continental areas with massive seasonal thunderstorms, or cold regions dominated by snowmelt. However, in some cases, grasslands occur where $>65 \%$ of precipitation demand is met, and fire and grazing probably limit forest development. If fire is to carry successfully and to kill trees and shrubs, moisture must be sufficient for a continuous biomass density (fuel load) to develop and seasonal dry periods must exist during which fires can spread. Large herbivores also can inhibit dominance of trees in some conditions (e.g., elephants in savannahs; Dublin et al. 1990), and factors, such as flooding or inundation, may inhibit tree development (e.g., flooded grasslands, such as those that occur in parts of the Everglades or the Pantanal). In these areas, perennial flow is expected to be more common.

\section{GEOMORPHOLOGY ACROSS BIOME GRADIENTS Geomorphology and biomes}

The interactions of regional climate regimes, geology, soils, vegetation, topography, and human influences combine to produce the characteristic geomorphology and hydrology of watersheds. Flashiness, and as a consequence, flood power and sediment movement are expected to be 
Table 3. Summary of predicted characteristics of headwater streams along a gradient from desert to forest. Trends are generalities for streams draining each habitat type.

\begin{tabular}{|c|c|c|c|c|}
\hline Category & Aspect & Desert & Grassland & Forested \\
\hline \multirow[t]{3}{*}{ Hydrology } & Continuity of discharge & $\begin{array}{l}\text { Ephemeral/ } \\
\text { intermittent }\end{array}$ & $\begin{array}{l}\text { Intermittent/ } \\
\text { perennial }\end{array}$ & Perennial \\
\hline & Flashiness & High & Intermediate & Low \\
\hline & Discharge & Losing & Mixed & Gaining \\
\hline \multirow{17}{*}{$\begin{array}{l}\text { Geomorphology and } \\
\text { controls on hydrology }\end{array}$} & $\begin{array}{l}\text { Flow accumulation } \\
\text { Width/depth }\end{array}$ & Losing & $\begin{array}{l}\text { Mixed } \\
\text { Medium }\end{array}$ & Gaining \\
\hline & Width & High & Intermediate & Low \\
\hline & Depth & Shallow & Intermediate & Deep \\
\hline & Soil water storage & Poor & Intermediate & Substantial \\
\hline & Soil organic content & Low & Medium & High \\
\hline & Infiltration capacity & Low & Medium & High \\
\hline & Bank stability & Unstable & Intermediate & Stable \\
\hline & Bed load : suspended load & Highest & Intermediate & Lowest \\
\hline & Dynamic equilibrium & Furthest & Intermediate & Closest \\
\hline & Rain splash, sheet wash, rill formation & Most common & Intermediate & Least common \\
\hline & $\begin{array}{l}\text { Aeolian influence on sediment } \\
\text { concentration and flow paths }\end{array}$ & High & Low & Lowest \\
\hline & Drainage density & Low & Medium & High \\
\hline & Braiding & More common & Less common & Rare \\
\hline & Anthropogenic effect on flow & High & Medium & Low \\
\hline & Longitudinal complexity & Lowest & Intermediate & Highest \\
\hline & Habitat heterogeneity & Lowest & High/intermediate & Highest \\
\hline & Temperature variance & High & High/moderate & Low \\
\hline \multirow[t]{6}{*}{$\begin{array}{l}\text { Terrestrial biome } \\
\text { influence }\end{array}$} & Canopy cover & Open & $\begin{array}{l}\text { Mixed, increasing } \\
\text { downstream }\end{array}$ & Closed \\
\hline & Primary energy source & Autochthonous & Mixed & Allochthonous \\
\hline & $\begin{array}{l}\text { Interannual variation of terrestrial } \\
\text { allochthonous inputs }\end{array}$ & Low & High & Low \\
\hline & Vegetative control of geomorphology & Low & Medium & High \\
\hline & $\begin{array}{l}\text { Large herbivore influence on } \\
\text { geomorphology }\end{array}$ & Low & High & Medium \\
\hline & Large woody debris & Rare & Modest & Common \\
\hline \multirow{5}{*}{$\begin{array}{l}\text { Water quality and } \\
\text { nutrients }\end{array}$} & Sediment transport/concentration & High & Medium & Low \\
\hline & Total $\mathrm{N}$ and $\mathrm{P}$ & Low & Low & Low \\
\hline & C content & Lowest & Intermediate & Highest \\
\hline & Mineral : organic sediment & Highest & Intermediate & Lowest \\
\hline & Anthropogenic effect on water quality & High & Very High & Medium \\
\hline \multirow[t]{7}{*}{ Animals } & Vertebrate richness & Low & Medium & High \\
\hline & Vertebrate endemism & Low & Medium & High \\
\hline & Fish life history & Opportunistic & Opportunistic & Stable \\
\hline & Invertebrate richness & Low/medium & Medium & High \\
\hline & Invertebrate endemism & Medium & Low & High \\
\hline & Invertebrate production & High & High & Medium \\
\hline & $\begin{array}{l}\text { In-channel flora and fauna influence } \\
\text { on stream structure }\end{array}$ & Low & Medium & Highest \\
\hline
\end{tabular}




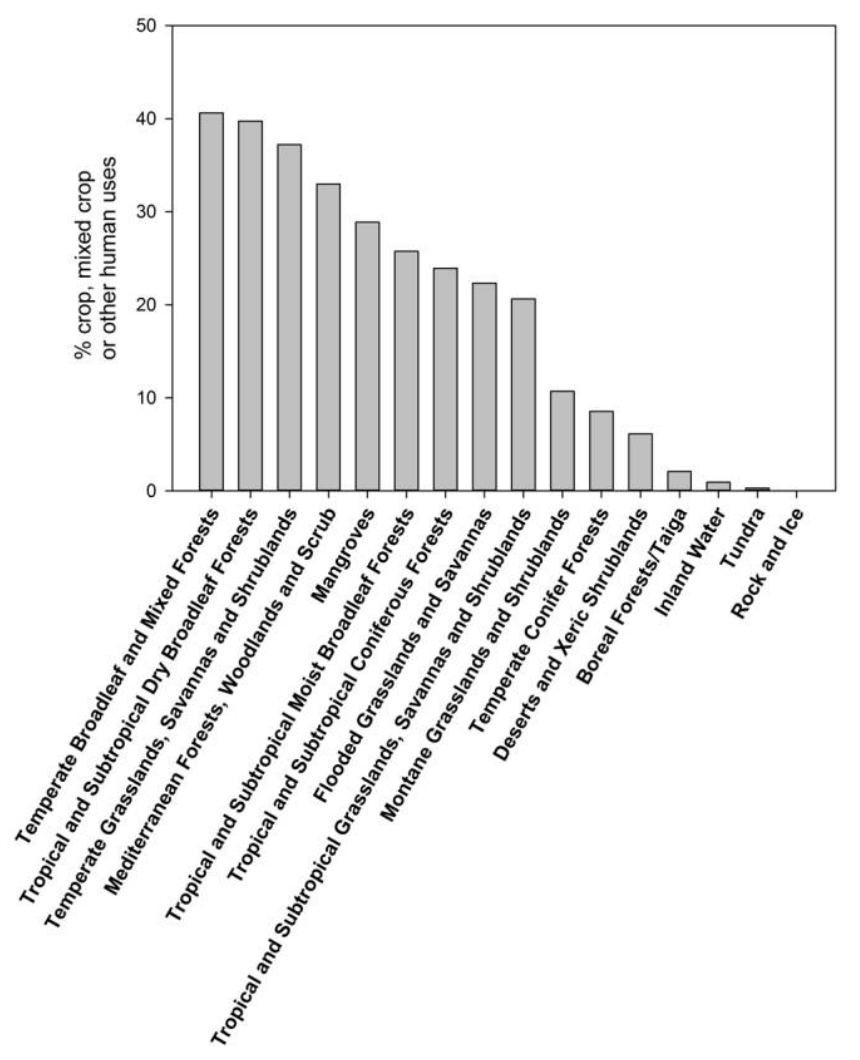

Figure 2. Percentage of major biomes in crop, mixed cropland, and other human uses. Global land cover data (year 2000) from http://bioval.jrc.ec.europa.eu/products/glc2000/glc2000.php and overlaid on data from http://conserveonline.org/workspaces /ecoregional.shapefile.

greatest in the driest regions (Table 3). Vegetative, climatic, and hydrologic factors, in part, determine soil characteristics. In general, deserts have more bare ground and poorly developed (shallow) soils, so water storage is limited. Flashiness is compounded by low infiltration capacity consequent to low organic content and no vegetation interception. Low infiltration produces Hortonian (infiltration excess) overland flow and flash floods (Horton 1945). Sediment supply is enhanced via wind-driven (aeolian) delivery to the stream network in drier areas (e.g., Langford 1989). Accordingly, desert streams have the highest recorded bedload-discharge relationships in the world (Cohen and Laronne 2005) and usually consist of shallow stream channels with high sediment concentrations during effective discharge events (Simon et al. 2004).

Riparian and hillslope vegetation density, soil depths, infiltration capacity, and bank and channel stabilization by vegetation will increase as precipitation increases along the spectrum from arid to more mesic systems. These combined changes result in reduced hydrologic flashiness and lower sediment concentrations in wetter areas. In grasslands, comparatively deep soils, high organic content, and nearly $100 \%$ vegetative cover (except in overgrazed areas) all combine to modulate the hydrologic response to intense precipitation events (Fig. 3). Thus, as in forests, many grasslands require extensive saturation to produce flash floods, but the increased seasonality and intensity of precipitation combined with lower magnitude and duration of base flows magnifies the flashy nature of grasslandstream flood regimes.

The conventional understanding is that, along a transition from desert (arid) to forest (mesic) biomes, both vegetation and hydrologic regimes interact to form characteristic channel morphology and sediment dynamics that reflect these $1^{\text {st }}$-order controls. However, aspects of this model also can apply to within-biome gradients as broadly defined by form of dominant vegetation. For example, grasslands can occur from mesic to arid conditions (Fig. 3). The range of grassland hydrogeomorphological characteristics illustrates that a simple view of gradients from forest to desert is just one way to view biome gradients and fails to capture some important patterns. Plant growth-form alone is a coarse way to characterize biome characteristics.

Forested streams have been considered in the framework of a dynamic equilibrium (a most probable geomorphologic state in an inherently variable system; Leopold 1994), but generalizations from forested streams may not hold true in streams with more episodic (e.g., intermittent or ephemeral) flow (Merritt and Wohl 2003) and less vegetative stabilization of stream channels. As such, desert streams should be further from dynamic equilibrium, forested streams should be closest, and grassland streams should be intermediate. This equilibrium, in turn, will influence formation of oxbows and side channels and relative abundance of other habitat types (e.g., riffles and pools).
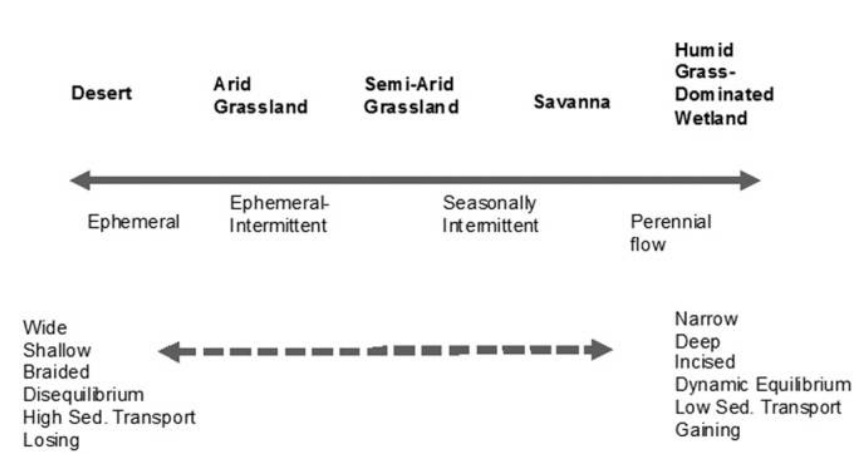

Figure 3. Climate, biome hydrologic regime, and stream geomorphology for a gradient of grassland types based on hydrology. This figure shows how gradients can occur within a biome type. Sed. = sediment. 
Channel widths relative to their respective drainage area may vary across climate gradients. In grasslands, grass roots stabilize channel margins. In forests, trees strongly influence most natural stream channels. Damming by large woody debris jams can widen channels in small streams, but in larger streams, riparian trees can constrain channel widths and facilitate natural levy formation. Extreme floods lead to very wide channels in ephemeral streams that recover slowly during long periods of stable or no flow as woody riparian vegetation becomes re-established (Friedman and Lee 2002). Geomorphic changes from floods of equal recurrence intervals are expected to be greatest in desert systems. We expect broad channels to be most common in desert streams, least common in forested streams, and intermediate in dry grassland streams. However, stream channels in naturally forested areas are wider in forests (where root stabilization and introduction of woody debris combine to widen channels) than in grassdominated pastures that have been converted from forests (Davies-Colley 1997, Sweeney et al. 2004, McBride et al. 2010). Widening by tree roots in low-order streams also can occur in more mesic grasslands. Thus, small-scale variation in stream width can be controlled by local riparian vegetation, but overall width also is related to broad climatic patterns.

The influences of biome on geomorphologic processes suggest that during times of continuous flow, sediment loads should be greatest in the driest habitats. Watercolumn suspended sediment concentrations are higher and particulate $\mathrm{C}$ content is lower in human-modified areas that were historically grasslands than in forested areas (Dodds and Whiles 2004). Streams draining relatively pristine grasslands have suspended sediment concentrations as low or lower than those draining most forested regions (Whiles and Dodds 2002). Suspended sediment is expected to have higher mineral to organic ratios in desert than in forested streams because of less chemical weathering and riparian deposition. Moreover, a greater portion of the dissolved load in deserts probably consists of evaporates that increase salinity (Langford 1989).

\section{Interactions with other factors influencing geomorphology}

Grazing and fire interact to shape terrestrial biomes. So in addition to climate effects on hydrology and geomorphology already discussed, influences of fire and grazing may vary across biome gradients and have differential influences on streams (Fig. 4). We hypothesize that across precipitation gradients, grazing effects are strongest in grasslands and become less influential as one moves from grasslands into forest or desert. In general, we expect fire to be a terrestrial process that influences natural grasslands more regularly than desert or forested grasslands. How-

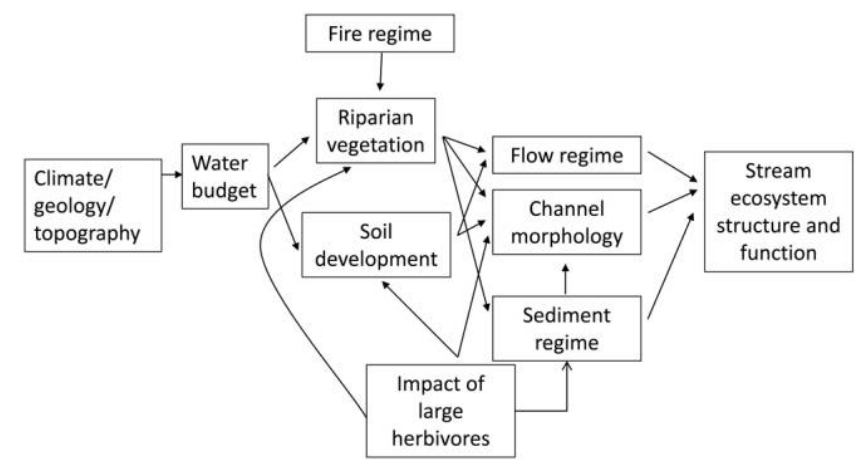

Figure 4. Conceptual diagram of the factors proposed to alter stream ecosystem structure and function as mediated by stream geomorphology and hydrology as they vary across largescale biome gradients. Effects of fire and large herbivores are expected to be greatest in natural grasslands when livestock is added to drier habitats or when forest is converted to pasture. Riparian vegetation can stabilize stream banks, alter runoff, and (in small streams) influence channel width and depth. We expect different controlling factors to take precedence depending on the terrestrial context. See text for detailed explanation.

ever, fire can be more catastrophic with respect to sediment and nutrient input to streams in forested and desert systems because much grassland biomass is below ground, meristems are protected, stem densities are high (many small stems), and fibrous root morphology is common. Subsequently, grasslands recover very quickly after fire, and sediments and nutrients are held in place (Dodds et al. 1996, Larson et al. 2013b). In contrast, fires in deserts and dry shrublands remove already sparse vegetation (assuming vegetation is dense enough to carry fire), which can take a long time to regenerate, leading to runoff events across exposed soil (Malmon et al. 2007). In many forests, combustion of large amounts of biomass and forest floor litter leads to significant amounts of ash that can be mobilized to stream channels (Ice et al. 2004).

Large animals can substantially affect geomorphology in all biomes (Naiman and Rogers 1997). Grasslands probably had the greatest natural biomass density of large terrestrial grazers across the global biome gradient. Desert vegetation is too sparse to support large populations of herbivores, and much of forest vegetation is high in the canopy and out of reach of large ungulate grazers. Potential differences between native (e.g., bison, or the large grazing communities of the African savannas) and nonnative (e.g., cattle) grazer effects on stream geomorphology are not well understood. Bison increase bare sediments from pawing and wallowing, but minimally increase suspended sediments in tallgrass prairie streams (Larson et al. 2013b). Cattle grazing can increase sediment concentrations and affect macroinvertebrate diversity in Mongolian Steppe streams (Hayford and Gelhaus 2010). The lack of information about the influence of cattle grazing on 
grassland stream geomorphology is an important knowledge gap considering that grasslands naturally had high biomass of large grazing animals.

Increased grazing pressures occur in forested areas that have been converted to pastures and deserts where water can be supplied. Globally, the total biomass of cattle in the year 2000 exceeded the estimated biomass of all mammals (native and domestic) in 1900 by $8 \times$ (Smil 2011), suggesting that regardless of biome, cattle are having a much greater effect on streams now than at any time in human history. When grazing pressure is increased, grasslands' and even forests' geomorphic systems may be pushed toward a state more characteristic of a desert biome by decreasing riparian biomass, resulting in reduced cover and increased patches of bare ground (Teague et al. 2010). The riparian changes induced by activities of cattle increase the influence of rain splash, sheet wash, and rill formation and can induce gully development (Bartley et al. 2010). Within the immediate channel and riparian environments, cattle grazing degrades stream banks, alters hydrologic and sediment processes, changes channel geometry by increasing width to depth ratios (Trimble and Mendel 1995), and dramatically increases suspended sediment yields (Vidon et al. 2008). Other effects include altered light penetration, in-stream water temperature, and habitat structure (Fig. 4). Increased hillslope erosion, vegetation removal, and channel trampling create abundant loose sediment, high bedload-discharge relations, and destabilized channel boundaries.

Human alterations to watersheds can radically alter the expectation that sediment loads are greatest in drier regions through watershed disturbances including intensive deforestation, agricultural conversion or livestock production, and dam construction. Dense livestock and other watershed disturbances can dramatically increase sediment loads, even in streams draining mesic areas. Any process that decreases vegetative cover (logging, conversion to row-crop agriculture) has the potential to increase sediment loads regardless of the biome in which it occurs.

\section{ECOSYSTEM PROPERTIES ACROSS BIOME GRADIENTS Nutrients}

Biome gradients modestly influence stream nutrient concentrations based on data from the contiguous USA, but little is known about nutrient levels across broad sections of tundra, tropical habitats, or other areas that have received less research. Several analyses of nutrient concentrations in North America indicate that baseline nutrient concentrations are broadly similar across ecoregions in undisturbed watersheds (Smith et al. 2003, Dodds et al. 2009). However, the data suggest that streams draining regions where tallgrass prairie and shortgrass prairie existed historically had relatively lower total $\mathrm{N}$ and greater total $\mathrm{P}$ concentrations than reference streams in other regions. We expect increasing sediment loads across a gradient from deserts to forests (Table 3). P is often correlated with sediments, a situation that leads to an expectation that total P should be higher in drier ecosystem streams.

Fires can occur in any biome and can influence baseline water quality across biome gradients. Fire maintains grasslands but probably has more modest effects on nutrient content in grassland streams than in forest or desert streams. Post-fire ash flows in dry areas can drastically increase nutrients (Earl and Blinn 2003) and, ultimately, can cause great harm to existing biota. Forest fires generally increase nutrient loads (e.g., Minshall et al. 1989, Bayley et al. 1992). In some grassland studies, nutrients increased after burning (e.g., Dodds et al. 1996), but in others, nutrients decreased after burning (Larson et al. 2013a, b). The large stock of belowground biomass in grasses and the fire tolerance of many species means that soil cover returns rapidly after grassland fires. In forests, fires lead to extended periods of bare ground during which the high-nutrient ash can wash into streams with heavy rainfall, whereas in grasslands, fire does not always penetrate wetter forested riparian zones that provide a buffer between the stream and burned hill slope.

We expect that large grazers are most common on grasslands relative to in other biomes. The effects of bison grazing on water quality in intact tallgrass prairie streams are moderate (Dodds et al. 1996, Larson et al. 2013b). Kemp and Dodds (2001) observed an 50\% increase in total $\mathrm{N}$ content in stream water following introduction of modest densities of bison on the Konza Prairie Biological Station in eastern Kansas. The effects of other large native mammalian grazers in other grasslands are poorly characterized. Exclusion of cattle from riparian zones can strongly influence riparian vegetative structure and alter rates of in-stream nutrient processing (Van Horn et al. 2012).

Humans can greatly increase nutrients in streams, and these effects seem to override climate-driven biome effects, such as greater total $\mathrm{P}$ and sediment in drier biomes. Cropland is a major source of nutrients (Banner et al. 2009). Increases in nutrients and other contaminants can be closely linked to landuse practices in the riparian zones of the lowest-order streams (Dodds and Oakes 2008). More than $90 \%$ of US streams exceed median reference levels for $\mathrm{N}$ except in the mountainous west, and $\mathrm{P}$ is increased in many streams with little association with biome (Dodds et al. 2009). These nutrient effects can cascade to biota, and nutrients from land use have decreased the diversity of in-stream biota across a broad sample of streams in biomes ranging from deciduous forest Ozark watersheds to xeric watersheds of the US High Plains (Evans-White et al. 2009). 


\section{Trophic state}

Stream metabolism is an important indicator of stream trophic state. Metabolism is a function of gross primary productivity (GPP) and ecosystem respiration (ER), and these rates can indicate the relative importance of various energy inputs to the system (i.e., autotrophic and heterotrophic state). Aquatic features that drive stream metabolism can vary monotonically across biome gradients, but variation in those features may not. For example, canopy cover is intimately related to the balance between autotrophic and heterotrophic state. Small forested streams have closed canopies for at least part of the year, and desert streams tend to have open canopies. Grassland streams are intermediate and highly variable with respect to woody vegetative cover near the stream channel (Dodds et al. 2004, Feijoó and Lombardo 2007). This canopy variation can have large effects on food webs by determining source and timing of organic $\mathrm{C}$ inputs to streams.

Seasonality driven by climate also can mediate the interaction between terrestrial plants and streams that flow past them. For example, seasonal leaf loss in dry tropical forests or temperate deciduous forests may lead to pulses of organic $C$ input and substantial increases in light reaching the streams. In addition, annual variability of precipitation can affect the net annual primary productivity of terrestrial habitats around streams, particularly in grasslands (Knapp and Smith 2001).

Across streams spanning a precipitation gradient from desert to forest, light is a primary driver of GPP (Bernot et al. 2010) but has little influence on ER. Of 5 biomes examined, Kansas grassland reference streams and desert streams had relatively high GPP compared to forested systems, as would be expected for areas with relatively open canopy (Fig. 5A, Table 3). In this respect, canopy cover is a primary determinant of GPP across a gradient from closed to open canopy, either desert to forest or tundra to forest, leading to a shift of net ecosystem production (Fig. 5C) being closer to 0 in open-canopy streams.

We do not expect ER to vary across precipitation gradients (Fig. 5B, Table 3). Webster et al. (2003) parsed out the heterotrophic and autotrophic components of stream metabolism. They used this approach to explain the somewhat constant $\mathrm{N}$ uptake across 8 relatively pristine sites from tropical forest to Arctic tundra (Fig. 5D). They hypothesized that metabolic compensation (sources of $\mathrm{C}$ substitute for each other) was operating, such that streams with high algal production had low allochthonous inputs and those with high allochthonous inputs had low autochthonous inputs. Essentially, this hypothesis is light-driven, i.e., the energy from the light reaching the stream can be used by producers to fix $\mathrm{C}$ in the stream (open canopy) or by riparian producers that fix $\mathrm{C}$ out of the stream and then drop their leaves and leach $C$ into the stream (closed canopy). If this hypothesis holds, total incoming $\mathrm{C}$ flux should not vary across a gradient of canopy cover. However, in seasonal systems, the $\mathrm{C}$ influx from allochthonous sources

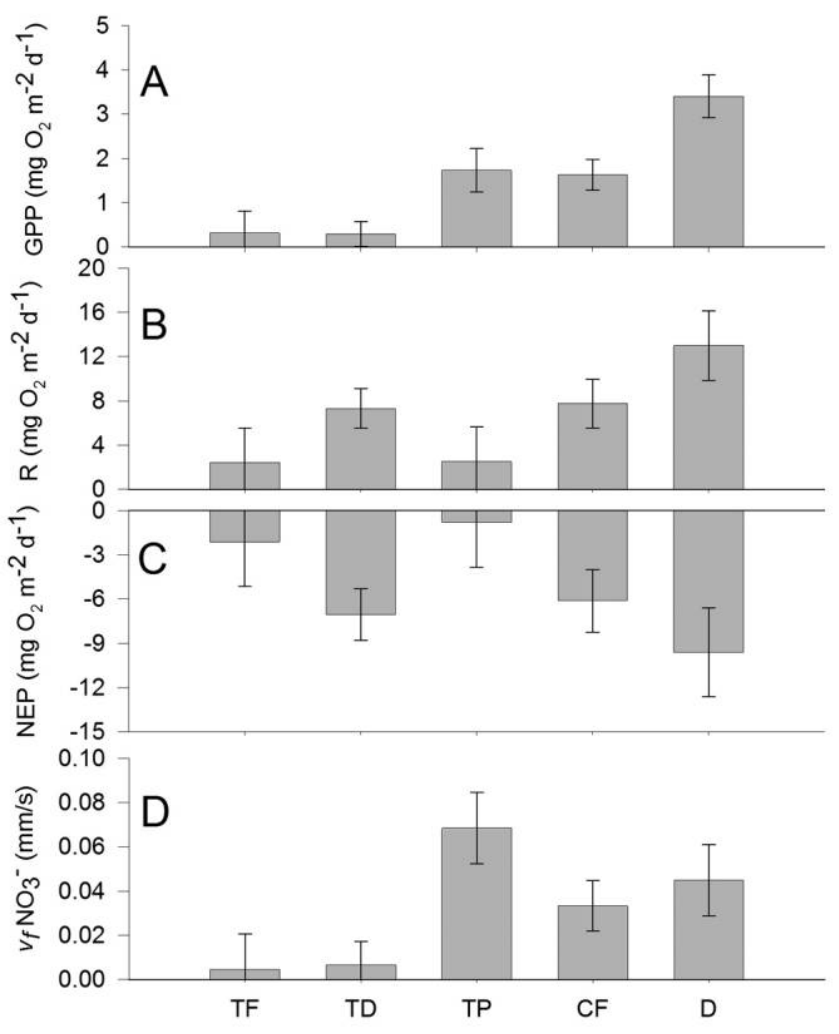

Figure 5 . Mean $( \pm 1 \mathrm{SE})$ gross primary productivity (GPP) (A), ecosystem respiration (R) (B), net ecosystem production $(\mathrm{NEP})(\mathrm{C})$, and $\mathrm{NO}_{3}{ }^{-}$uptake velocity $\left(V_{f}\right)(\mathrm{D})$ for streams in 5 biomes in North America. Analysis of variance indicated significant differences for GPP $(p=0.00026)$ and $V_{f}(p=0.031)$, but not ER and NEP $(p>0.05)$. Data for GPP, ER, and NEP are from Bernot et al. (2010), data for $V_{f}$ are from Mulholland et al. (2008). $\mathrm{TF}=$ tropical forest, $\mathrm{TD}=$ temperate deciduous forest, $\mathrm{TP}=$ tallgrass prairie, $\mathrm{CF}=$ coniferous forest, $\mathrm{D}=$ desert.

can vary strongly with time. The interannual variation of terrestrial primary productivity is expected to be greater in grasslands than forests or deserts (Knapp and Smith 2001), and the least seasonal habitats with respect to allochthonous inputs probably are tropical rainforests.

\section{STREAM ANIMAL COMMUNITIES ACROSS BIOME GRADIENTS Vertebrate diversity}

Analyses of several biomes suggest that, in general, forests have the highest freshwater vertebrate richness and endemism, followed by grasslands and then deserts (Fig. 6A-E, Table 3). These data may be influenced by lakes because more lakes occur in forested areas than in other biomes. However, the pattern holds when considering results from areas with only moderate numbers of natural lakes (unglaciated). We expect that the higher species richness in forested systems is because the area of habitat is greater (i.e., species-area relationships are important determinants of aquatic vertebrate species richness). 

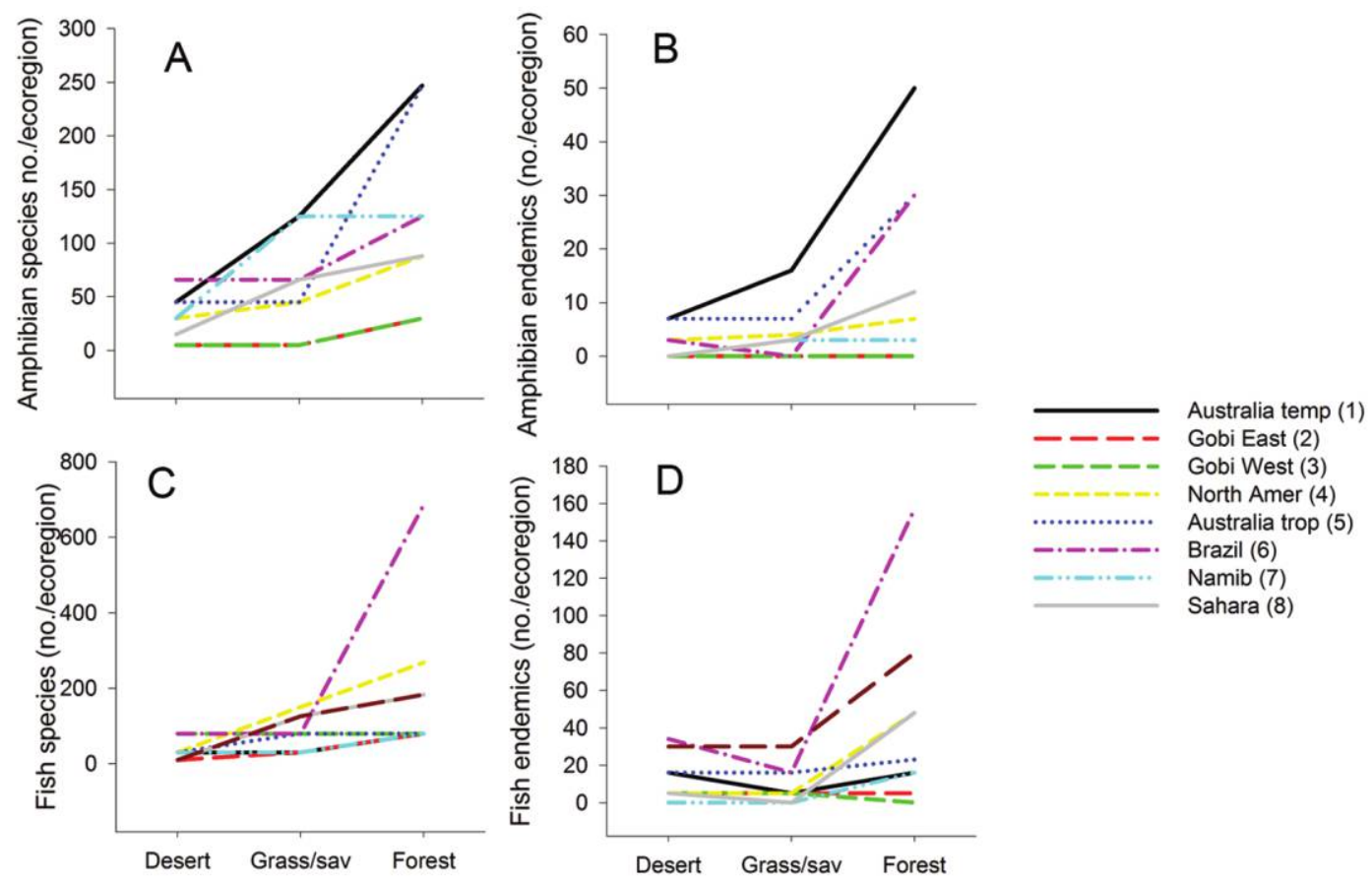

Gobi East (2)

Gobi West (3)

Australia trop (5)

Sahara (8)

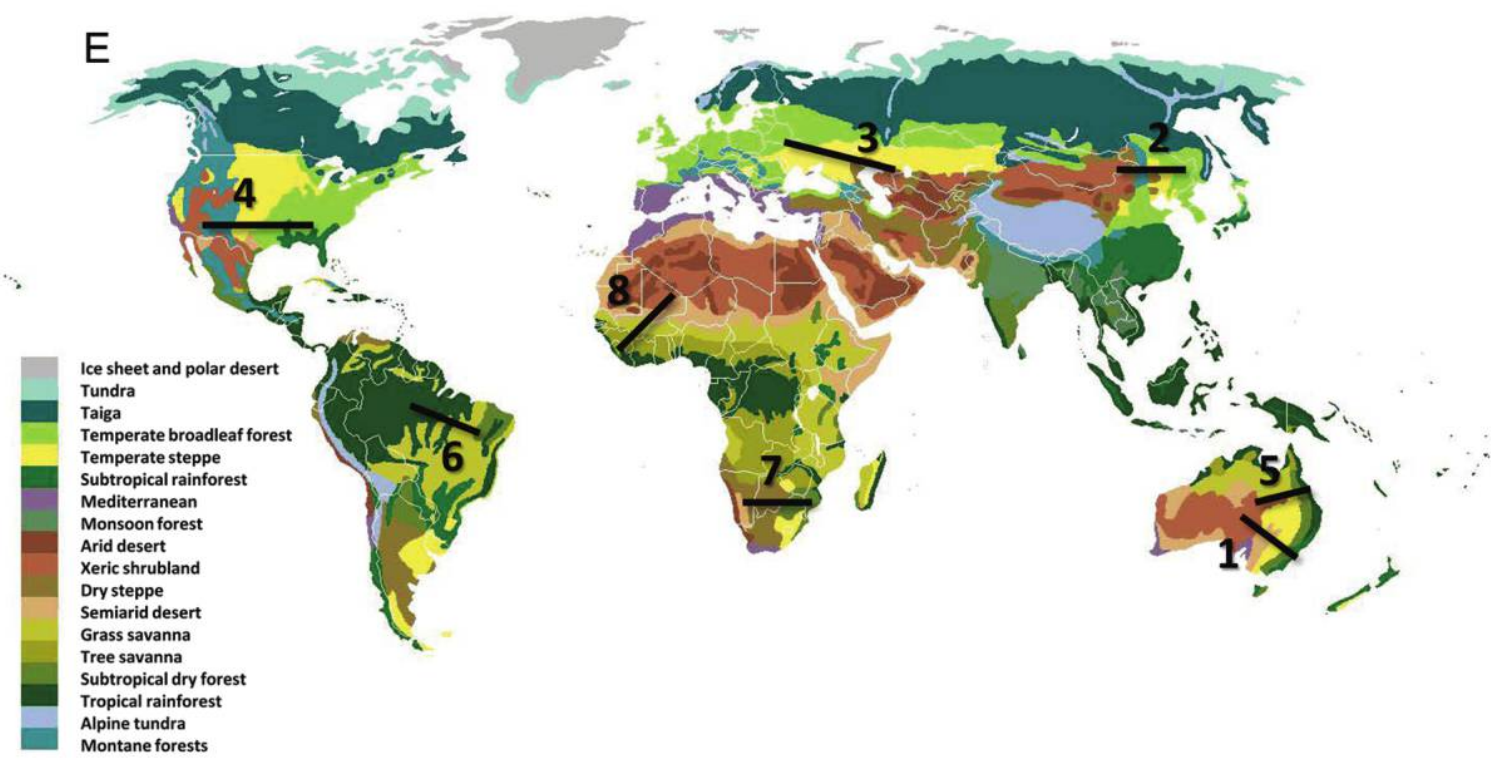

Figure 6. Total (A) and endemic (B) amphibian species and total (C) and endemic (D) fish species in freshwater ecoregions across continental gradients from deserts, through grasslands/savannahs, to moist forests. Transects are based on terrestrial ecoregion classifications by Olson et al. (2001) and are indicated by the black lines on the lower map (E). Numbers in the key to symbols correspond to transect lines in (E). Transects were selected to move across biome types across relatively constant latitude. Numbers of species were based on maps from Freshwater Ecoregions of the World (http://www.feow.org/index.php) and were taken from the ends of the lines (forest and desert) and the center of the grassland biome that is crossed $(\mathrm{E})$. Temp $=$ temperate, trop $=$ tropics, Amer $=$ America. Background biome image from http://en.wikipedia.org/wiki/Plant_ecology\#mediaviewer/File:Biomes.jpg

Latitudinal gradients also are important to biodiversity. Tropical areas have greater freshwater fish species richness compared to temperate areas (Allan and Flecker 1993, Matthews 1998). This pattern does not hold for salamanders, which are absent at very high latitudes and more diverse in temperate regions of the northern hemisphere than in the tropics (Pough et al. 2003), but diversity of anurans (frogs and toads) is greatest in tropical regions. For amphibians in general, diversity and endemism are greater in forest habitats (tropical or temperate) than in grasslands or deserts (Pough et al. 2003; Fig. 6A, B). Not all amphibians are closely associated with streams, but the 
subset that is associated with flowing waters probably follows the general patterns of the group as a whole across biomes and latitudes.

In general, rates of amphibian endemism per freshwater ecoregion are lowest in large, connected continental areas (e.g., across Northern Europe and Asia; Fig. 6B). At regional scales, intermittent conditions of grassland streams and the disconnected nature of desert and grassland streams compared to forested streams (e.g., high geographic isolation related to low drainage density) could facilitate high rates of endemism. However, this expectation does not appear true with respect to stream fishes and amphibians (Fig. 6B, D). For example, although some isolated streams and springs in arid grassland regions of the southwestern USA harbor endemic salamander species (e.g., Eurycea spp. in the Edwards Plateau region; Lucas et al. 2009), salamander endemism is more prevalent in the moist, forested Appalachian region. Similarly, amphibian diversity and endemism are surprisingly high in freshwaters found in the harsh arid regions of Australia, but still less than in the forested regions of Australia (Fig. 6A, B).

Limited habitat and species diversity constrain the degrees of endemism of stream vertebrates in arid and semiarid regions, but low endemism may also reflect adaptive strategies over evolutionary time scales, such as longdistance dispersal to escape inhospitable conditions and to seek out optimal conditions. For example, in North American grassland rivers, many species are known to migrate tens to hundreds of kilometers upstream (e.g., some sturgeon species, silvery minnows).

\section{Invertebrate diversity}

Patterns of diversity across biomes are not as well understood for stream invertebrates as for vertebrates, in part, because in most investigations of stream invertebrate communities, individuals are not identified to the species level, or only subsets of the invertebrate community (e.g., only insects) are examined. The pattern of high fish diversity in tropical streams does not seem to apply to most invertebrates. Stream invertebrate diversity is low at the highest latitudes, but temperate zones often have invertebrate diversity as great as or greater than comparable tropical areas (Allan and Flecker 1993, Pearson and Boyero 2009). The difference between fish and invertebrate diversity across latitudes could be driven by the fact that many adult aquatic invertebrates (e.g., insects with winged adults) can disperse across watersheds more easily than fishes, whereas in areas with high stream density, gene flow in many populations of fishes is restricted because of the more limited dispersal (Turner and Trexler 1998). Thus, it is likely that fish and amphibians have been less able to disperse into areas strongly influenced by glaciation and climate change than invertebrates with flying adult stages or with a smaller body size that makes them more likely to be moved by waterfowl and other dispersal agents (Mandrak and Crossman 1992).

Studies of stream invertebrate communities in North American desert (e.g., Jackson and Fisher 1986, Stanley et al. 1994), grassland (e.g., Fritz and Dodds 2002, Stagliano and Whiles 2002, Whiting et al. 2011), and forested (e.g., Gladden and Smock 1990) regions suggest that relatively few taxa are unique to grassland streams, with some notable exceptions, such as the Platte River caddisfly (Ironoquia plattensis) (Whiles et al. 1999) and Scott riffle beetle (Optioservus phaeus) (White 1978). Aquatic invertebrate endemism can be high in arid regions, where species are often associated with isolated springs or wetlands (Whiteman and Sites 2008).

Invertebrate taxonomic richness in grassland streams can be highly variable but often is intermediate between desert and forested streams, and many taxa found in desert and forested systems also are present in grassland streams. Comparison of invertebrate communities in small perennial streams in coastal forests and in continental arid grasslands in British Columbia indicated that grassland streams had lower richness and $\sim 1 / 2$ as many unique taxa as the forested streams, although invertebrate densities were higher in the grassland streams (Reece and Richardson 2000). Among grassland streams, invertebrate diversity often is greater in streams that flow for longer periods of the year or year-round, although time since last hydrologic disturbance can override this pattern (Fritz and Dodds 2002).

Given the paucity of data sets on stream invertebrates available for many biomes, synthetic efforts might yield broader conclusions across biome gradients. Such efforts might include harvesting unpublished data, data from many site-specific publications, or additional sampling.

\section{How ecological responses of animals change across biome gradients}

Riparian cover can influence water temperature, inputs of detritus, and terrestrial invertebrate prey. Subsidies of aquatic food webs from terrestrial sources can be a key component of many stream systems (e.g., Nakano and Murakami 2001, Allan et al. 2003). Temperature and source of organic materials are dominant factors linking surrounding riparian cover with stream animal communities. Water temperature in grassland streams probably is greater than in forested streams in similar climatic zones because of the open canopies and greater light penetration characteristic of grassland streams. Riparian cover is hypothesized to influence fish or amphibian occurrence and abundance in Northern California (Welsh et al. 2005) and Japan (Inoue and Nunokawa 2005, Nakamura and Yamada 2005). However, Dineen et al. (2007) found that riparian cover did not influence stream water temperature in for- 
ested Northern Ireland, and speculated that increased terrestrial subsidies in forested streams were important in maintaining growth of trout. Saunders and Fausch (2007) showed that intensive grazing by livestock reduced riparian vegetation and led to decreased input of terrestrial invertebrates, thereby reducing foraging opportunities for trout in mountain grassland streams.

Structural heterogeneity with respect to stream habitat also might differ between forest and grassland streams and cascade to the community. However, Teresa and Romero (2010) found that a shift in riparian vegetation from wet grassland to gallery forest in a Brazilian savanna stream coincided with a shift in fish community composition and noted that upstream reaches with grassland had high structural diversity because grasses, bushes, and roots provided unique habitats for many fishes (e.g., Gymnotiformes and Siluriformes). We are unaware of studies comparing fish communities in desert and grassland streams, but would expect greater light and lower riparian subsidies across the gradient from grassland to desert streams.

Invertebrate taxonomic diversity is generally lower in grassland streams than in similar-sized forested systems. However, estimates of invertebrate abundance, biomass, and production from prairie (e.g., Stagliano and Whiles 2002, Whiting et al. 2011) and desert (e.g., Fisher and Gray 1983) streams often exceed those from their forested counterparts, a pattern noted by Benke (1993) in a meta-analysis of stream invertebrate production studies. For example, invertebrate production in Sycamore Creek, a warm Sonoran Desert stream, was estimated at 121 to $135 \mathrm{~g}$ dry mass (DM) $\mathrm{m}^{-2} \mathrm{y}^{-1}$ (Fisher et al. 1982), compared to estimates from temperate grassland streams, which are quite variable, but generally fall in the range of $\sim 8$ to $50 \mathrm{~g} \mathrm{DM} \mathrm{m}^{-2} \mathrm{y}^{-1}$ (e.g., Huryn 1998, Whiting et al. 2011). Estimates of secondary production from Arctic tundra streams were orders of magnitude lower, ranging from 0.8 to $2.2 \mathrm{~g} \mathrm{DM} \mathrm{m}^{-2} \mathrm{y}^{-1}$ (Harvey et al. 1998). High invertebrate production in streams in warm arid regions has been attributed to high individual growth rates, which are linked to warm water temperatures and abundant food, e.g., from high in-stream primary production (Huryn and Wallace 2000, Benke and Huryn 2010). This is illustrated by life cycles of midges in Arctic tundra pools that can take 7 y (Butler 1982) compared to midges that complete their life cycles in $12 \mathrm{~d}$ in a Sonoran Desert stream (Jackson and Fisher 1986). High growth rates in intermittent streams also are the product of selection for species that can complete generations when streams are flowing seasonally (Huryn and Wallace 2000).

The more intermittent nature of desert and grassland streams should result in animal communities composed of species with higher resistance or resilience than in forested areas (e.g., high growth rates and short generation times; Huryn and Wallace 2000). In addition, effective dispersal is necessary for recolonization after strong dis- turbance (drying or extreme floods) and for individuals to capitalize on open habitats created by these periodic disturbances. More hydrologically variable arid grasslands are predicted to be dominated by $r$-selected (rapid growth and reproduction, high dispersal, poor competitors) species, whereas more mesic systems should have higher proportions of $\mathrm{K}$-selected (slower growth and reproduction, lower dispersal rates, high competitive ability) species. Hydrology influences trait distributions of fish (Mims et al. 2010) and invertebrate (Poff et al. 2006b) communities. In a study across North American biomes, Mims and Olden (2012) found that fish communities in streams with more volatile flow regimes were more likely to include species with rapid life cycles than those in streams with stable or predictable flows.

Foodweb structure should be more dynamic in grassland and desert streams than in forests and should be driven by the relative abundance of basal resources (e.g., algae, leaves, and other sources of organic C) and disturbance regime. Studies in grassland systems suggest that both top-down and bottom-up processes regulate foodweb structure (Huryn 1998, Stagliano and Whiles 2002, Nyström et al. 2003). Where dense canopy cover is lacking, reliance on autotrophic production should be greater (Whiting et al. 2011). Moreover, primary consumers should be favored in intermittent reaches of desert and grassland streams because the recovery of the microbial autotrophic food sources is rapid. In general, foodweb structure should vary with hydrology and degree of canopy cover. Sabo et al. (2010) found reduced food-chain lengths in systems with more variable hydrology and that top predators were dominated by piscivores in moreperennial systems and invertivorous predators in intermittent systems.

Animal communities in streams can have consequences for ecosystem functioning. Information comparing effects of stream consumers on ecosystem structure and function across biomes is limited. Grazing fishes can have strong effects on periphyton communities and nutrient cycling in desert (Grimm 1988) and grassland streams (Power et al. 1985, Murdock et al. 2010, Kohler et al. 2011) that have relatively high rates of autochthonous production. The role of shrimp and crayfish in litter processing probably increases in forested tropical and temperate streams (Huryn and Wallace 1987, Crowl et al. 2001). Top-down effects by insectivores and piscivores are more likely to be limited by disturbance regime and energy availability, as mentioned above.

\section{Anthropogenic influences on stream animals across gradients}

Major conservation challenges for stream animal communities include habitat and hydrologic modification (e.g., stream drying, sedimentation), fragmentation, and species 
introductions. These stressors occur across all biomes, but anthropogenic disturbances could have greater influence in arid and semi-arid regions because animals are already near their physiochemical extremes (Bramblett et al. 2005). Alternatively, some biomes are more prone to disturbance. For example, many grasslands have been converted to cropland (Fig. 2), potentially leading to stronger anthropogenic influence on stream animals in those habitats.

Depletion of aquifers drastically reduces stream habitat and is linked to species extirpations (e.g., Gido et al. 2010), and such depletion is expected to be more common in drier habitats with lower aquifer recharge rates. Impoundments alter hydrologic disturbance regimes, often stabilizing flows by limiting extreme high and low flow magnitudes and durations (Magilligan and Nislow 2005). Fragmentation by dams and road crossings blocks movement of animals, reduces the resilience of these dynamic communities (Fagan 2002, Perkin and Gido 2011), and may lead to extirpation of native species. Increases in sediment can change fish community composition by favoring tactile feeding species (e.g., catfishes with barbells) over visual feeders, such as many salmonids (Cross and Moss 1987). Sediment loads are expected to be greater in more xeric streams. If so, xeric biome streams should contain animals adapted to greater sediment concentrations. Deforestation and conversion to cropland vastly increase sediments in areas where native species may not be tolerant. Species invasions might be limited by the disturbance regime of grassland and desert streams, but low species diversity and highly modified hydrology exacerbate the probabilities of invasions (Moyle and Light 1996, Gido et al. 2004).

\section{THE STREAM BIOME GRADIENT CONCEPT AND OTHER INTEGRATIVE IDEAS IN LOTIC ECOLOGY}

Vannote et al. (1980) acknowledged that the RCC was based primarily on forested streams and that streams in other biomes would have different longitudinal patterns. Thus, the initial predictions of the RCC and the more detailed ones developed subsequently can be refined based on the biome under consideration. For example, many of the smallest desert, grassland, and tundra streams have open canopies, which will heavily influence energy flow and increase the relative importance of autochthonous production. However, total energy entering the system may not vary because of metabolic compensation (i.e., the energy from sunlight gets into the stream either via production in the stream or by production in the canopy over the stream). An expanded view of the RCC (see table 24.3 in Dodds and Whiles 2010) indicates many areas where the Stream Biome Gradient Concept could be applied to smallto medium-sized streams, including, but not limited to among-biome differences or gradients in: 1) the relative importance of seasonal variation in upstream-to-downstream temperature gradients for fish communities, 2) the effect of temperature on ER and patterns of ER and GPP from upstream to downstream, 3) the relative importance of woody debris from upstream to downstream, 4) variation in discharge patterns from upstream to downstream (e.g., in deserts, flow in losing streams and rivers may decrease downstream), and 5) frequency of sight-feeding by fishes along a dryland to forested stream gradient because of changing sediment loads along the gradient.

The Stream Biome Gradient Concept also could inform some RCC predictions about aspects of the very largest rivers, many of which cut across biomes. For example, many rivers that flow through deserts begin as montane streams and flow from their source through several biome types. Thus, large woody debris (in unimpounded systems) could move from areas with trees into areas that produce few large logs, adding another dimension to the Serial Discontinuity Concept (Ward and Stanford 1995).

Some aspects of rivers do not vary across biomes. For example, very large rivers tend to have slowly modulated hydrographs, have high turbidity, are more likely to have planktonic components, and receive materials from far upstream. Other aspects of rivers are clearly influenced by local biomes, such as small streams entering them and riparian wetlands. Thus, predictions of the FloodPulse Concept in larger rivers (Junk et al. 1989) could be influenced by biome as the floodplain and side-channel characteristics are shaped by the particular biome in which they occur. A flood plain of a large tundra river will not have large woody debris, whereas rivers in more temperate climates may have flood plains that are almost completely forested. In the tropics, floods are predictable over long enough time periods that specific adaptations to riparian flooding are found, including fish-dispersal of fruit seeds in flooded forest (e.g., Gottsberger 1978).

The Riverine Ecosystem Concept (Thorp et al. 2006) enables parsing the ecology of rivers that may be affected by biome gradients. It does so by considering functional units of different aspects in the river, some of which may be influenced by processes far upstream (possibly across biome gradients) and others by more-local processes, which could be biome specific. For example, some fish species require long migration distances to successfully complete their life cycle, so may cross biomes as they move through river networks, and others are more sedentary in side channels and are mainly influenced by local conditions. Cross-biome effects have been considered for some montane stream networks (Ponette-González et al. 2014), and this is a promising area for future research across other biomes. Large biogeographic effects on human impacts on rivers (macrosystems) are just now receiving consideration (McCluney et al. 2014), and cross-biome perspectives are necessary at this scale. 


\section{OVERVIEW}

Deserts and forests define the extremes of a moisture gradient, and characteristics of streams vary across this gradient (Table 3). Similarly, temperature (latitudinal) gradients begin in tundra, but can end in desert, grassland, or forest depending on the precipitation gradient. These gradients are reflected in strong differences in the abiotic template that constrains and shapes the ecological properties of lotic waters. When considered across broad biogeographic gradients, features, such as flow permanence, geomorphology, temporal patterns of hydrology, and baseline sediment and nutrient concentrations may vary. Such a view is implied by considering natural flow pattern across wide biogeographic areas (e.g., Poff et al. 1997). However, the predictions of the Stream Biome Gradient Concept (Fig. 1, Tables 2, 3), take this broad view further.

However, some contingencies will certainly limit predictive ability. Latitudinal effects differ for fish and invertebrate diversity, i.e., greater fish but not greater insect invertebrate diversity in tropical areas. In general, patterns of animal diversity can be driven by the same effects that drive differences in biomes, but evolutionary contingencies (e.g., biogeographic barriers, evolution of specific strategies) may confound some predictions related to the Stream Biome Gradient Concept.

All streams are influenced by anthropogenic disturbances, which might further confound predictive ability of cross-biome expectations. How those disturbances manifest themselves might be biome dependent. Anthropogenic disturbances from land use are common in temperate and tropical biomes and should disproportionally influence those streams because those areas are more heavily populated than other biomes. Most biomes have undergone agricultural conversions, especially temperate broad-leaved forests, tropical and subtropical dry forests, and temperate grasslands (Fig. 2). Grasslands commonly have rich soils and are easily modified for human agricultural uses, especially if livestock grazing also is considered. Boreal forests, tundra, and temperate coniferous forests are generally less disturbed, but global change and local pressures also have influenced them.

Still, understanding streams and their links to climate gradients could help predict how streams will appear globally in the future, particularly in light of declining freshwater supplies, global declines in freshwater biodiversity, and climate change. Streams draining modified terrestrial biomes could be forced by human activities to resemble those from other biomes. As examples, deforestation and hydrologic modification could change a forested stream so some of its characteristics resemble those of a grassland or desert stream (intermittent with open canopy), and water extraction in grasslands may push stream hydrology to more closely resemble desert streams. Irrigation and vegetation modification, particularly in urban areas, may cause arid-land streams that would usually be dry or ephemeral to flow more continuously, perhaps approximating forested streams.

Two key climate-controlled characteristics that affect many properties of streams are the presence or absence of a closed canopy over the stream and the proportion of bare ground in the catchment (Fig. 1). The presence/ absence of forest cover over a stream determines pathways of energy flow and drives community structure. Bare ground leads to altered runoff, geomorphology, and ultimately water quality. Consideration of streams across biome gradients allows predictions and comparisons of pattern across the largest spatial scale. Biome gradients are expected to be less pronounced for lentic habitats than for streams because lakes are not always as intimately connected to terrestrial habitats as streams. In contrast, a similar biome gradient approach may be very useful in wetland ecology. As stream scientists accrue more data and mechanistic studies, the Stream Biome Gradient Concept provides testable hypotheses (Fig. 1, Tables 2, 3) to guide synthetic and comparative research efforts.

\section{ACKNOWLEDGEMENTS}

We are grateful for support from the Konza Long-Term Ecological Research program, National Science Foundation Macrosystems grant EF1065255, and the International Grasslands Center. Ram Raghaven helped retrieving data for maps. Nancy Grimm, Janine Rüegg, and Danelle Larson provided helpful comments. This is contribution number 15-179-J from the Kansas Agricultural Experiment Station.

\section{LITERATURE CITED}

Abell, R., M. L. Thieme, C. Revenga, M. Bryer, M. Kottelat, N. Bogutskaya, B. Coad, N. Mandrak, S. C. Balderas, W. Bussing, M. L. J. Stiassny, P. Skelton, G. R. Allen, P. Unmack, A. Naseka, R. Ng, N. Sindorf, J. Robertson, E. Armijo, J. V. Higgins, T. J. Heibel, E. Wikramanayake, D. Olson, H. L. Lopez, R. E. Reis, J. G. Lundberg, M. H. S. Perez, and P. Petry. 2008. Freshwater ecoregions of the world: a new map of biogeographic units for freshwater biodiversity conservation. BioScience 58:403-414.

Allan, J. D., and A. S. Flecker. 1993. Biodiversity conservation in running waters. BioScience 43:32-43.

Allan, J. D., M. S. Wipfli, J. P. Caouette, A. Prussian, and J. Rodgers. 2003. Influence of streamside vegetation on inputs of terrestrial invertebrates to salmonid food webs. Canadian Journal of Fisheries and Aquatic Sciences 60:309-320.

Banner, E. B. K., A. J. Stahl, and W. K. Dodds. 2009. Stream discharge and riparian land use influence in-stream concentrations and loads of phosphorus from central plains watersheds. Environmental Management 44:552-565.

Bartley, R., J. P. Corfield, B. N. Abbott, A. A. Hawdon, S. N. Wilkinson, and B. Nelson. 2010. Impacts of improved grazing land management on sediment yields, part 1: hill slope processes. Journal of Hydrology 389:237-248. 
Bayley, S. E., D. W. Schindler, K. G. Beaty, B. R. Parker, and M. P. Stainton. 1992. Effects of multiple fires on nutrient yields from streams draining boreal forest and fen watersheds: nitrogen and phosphorus. Canadian Journal of Fisheries and Aquatic Sciences 49:584-596.

Beaulieu, J. J., J. L. Tank, S. K. Hamilton, W. M. Wollheim, R. O. Hall, P. J. Mulholland, B. J. Peterson, L. R. Ashkenas, L. W. Cooper, C. N. Dahm, W. K. Dodds, N. B. Grimm, S. L. Johnson, W. H. McDowell, G. C. Poole, H. M. Valett, C. P. Arango, M. J. Bernot, A. J. Burgin, C. L. Crenshaw, A. M. Helton, L. T. Johnson, J. M. O'Brien, J. D. Potter, R. W. Sheibley, D. J. Sobota, and S. M. Thomas. 2011. Nitrous oxide emission from denitrification in stream and river networks. Proceedings of the National Academv of Sciences of the United States of America 108:214-219.

Benke, A. C. 1993. Concepts and patterns of invertebrate production in running waters. Verhandlungen der Internationalen Vereinigung für theoretische und angewandte Limnologie 25:15-38

Benke, A. C., and A. D. Huryn. 2010. Benthic invertebrate production-facilitating answers to ecological riddles in freshwater ecosystems. Journal of the North American Benthological Society 29:264-285.

Bernot, M. J., D. J. Sobota, R. O. Hall, P. J. Mulholland, W. K. Dodds, J. R. Webster, J. L. Tank, L. R. Ashkenas, L. W. Cooper, and C. N. Dahm. 2010. Inter-regional comparison of land-use effects on stream metabolism. Freshwater Biology 55:1874-1890.

Bramblett, R. G., T. R. Johnson, A. V. Zale, and D. G. Heggem. 2005. Development and evaluation of a fish assemblage index of biotic integrity for northwestern Great Plains streams. Transactions of the American Fisheries Society 134:624-640.

Butler, M .G. 1982. A 7-year life-cycle for 2 Chironomus species in arctic Alaska tundra ponds (Diptera: Chironomidae). Canadian Journal of Zoology-Revue Canadienne de Zoologie 60:58-70

Cohen, H., and J. B. Laronne. 2005. High rates of sediment transport by flashfloods in the Southern Judean Desert, Israel. Hydrological Processes 19:1687-1702.

Cohen, J. E., and C. Small. 1998. Hypsographic demography: the distribution of human population by altitude. Proceedings of the National Academy of Sciences of the United States of America 95:14009-14014.

Cross, F. B., and R. E. Moss. 1987. Historic changes in fish communities and aquatic habitats in plains streams of Kansas. Pages 115-165 in W. J. Matthews and D. C. Heins (editors). Community and evolutionary ecology of North American stream fishes. University of Oklahoma Press, Norman, Oklahoma.

Crowl, T. A., W. H. McDowell, A. P. Covich, and S. L. Johnson. 2001. Freshwater shrimp effects on detrital processing and nutrients in a tropical headwater stream. Ecology 82:775783.

Davies-Colley, R. J. 1997. Stream channels are narrower in pasture than in forest. New Zealand Journal of Marine and Freshwater Research 31:599-608.

Dineen, G., S. S. C. Harrison, and P. S. Giller. 2007. Growth, production and bioenergetics of brown trout in upland streams with contrasting riparian vegetation. Freshwater Biology 52:771-783.

Dodds, W. K. 1997. Distribution of runoff and rivers related to vegetative characteristics, latitude, and slope: a global perspective. Iournal of the North American Benthological Society $16: 162-168$.

Dodds, W. K., J. M. Blair, G. M. Henebry, J. K. Koelliker, R. Ramundo, and C. M. Tate. 1996. Nitrogen transport from tallgrass prairie watersheds. Iournal of Environmental Ouality 25:973-981.

Dodds, W. K., W. W. Bouska, J. L. Eitzmann, T. J. Pilger, K. L. Pitts, A. J. Riley, J. T. Schloesser, and D. J. Thornbrugh. 2009. Eutrophication of US freshwaters: analysis of potential economic damages. Environmental Science and Technology 43:12-19.

Dodds, W. K., K. Gido, M. R. Whiles, K. M. Fritz, and W. J. Matthews. 2004. Life on the edge: the ecology of Great Plains prairie streams. BioScience 54:205-216.

Dodds, W. K., and R. M. Oakes. 2008. Headwater influences on downstream water quality. Environmental Management 41: 367-377.

Dodds, W. K., and M. R. Whiles. 2004. Quality and quantity of suspended particles in rivers: continent-scale patterns in the United States. Environmental Management 33:355-367.

Dodds, W. K., and M. R. Whiles. 2010. Freshwater ecology: concepts and environmental applications of limnology. $2^{\text {nd }}$ edition. Elsevier, Dordrecht, The Netherlands.

Dublin, H. T., A. R. E. Sinclair, and J. McGlade. 1990. Elephants and fire as causes of multiple stable states in the Serengeti Mara woodlands. Journal of Animal Ecology 59: $1147-1164$.

Earl, S. R., and D. W. Blinn. 2003. Effects of wildfire ash on water chemistry and biota in south-western USA streams. Freshwater Biology 48:1015-1030.

Evans-White, M. A., W. K. Dodds, D. G. Huggins, and D. S. Baker. 2009. Thresholds in macroinvertebrate biodiversity and stoichiometry across water-quality gradients in Central Plains (USA) streams. Journal of the North American Benthological Society 28:855-868.

Fagan, W. F. 2002. Connectivity, fragmentation, and extinction risk in dendritic metapopulations. Ecology 83:3243-3249.

Feijoó, C. S., and R. J. Lombardo. 2007. Baseline water quality and macrophyte assemblages in Pampean streams: a regional approach. Water Research 41:1399-1410.

Fisher, S. G., and L. J. Gray. 1983. Secondary production and organic-matter processing by collector macroinvertebrates in a desert stream. Ecology 64:1217-1224.

Fisher, S. G., L. J. Gray, N. B. Grimm, and D. E. Busch. 1982. Temporal succession in a desert stream ecosystem following flash flooding. Ecological Monographs 52:93-110.

Friedman, J. M., and V. J. Lee. 2002. Extreme floods, channel change, and riparian forests along ephemeral streams. Ecological Monographs 72:409-425.

Fritz, K. M., and W. K. Dodds. 2002. Macroinvertebrate assemblage structure across a tallgrass prairie stream landscape. Archiv für Hydrobiologie 154:79-102.

Gido, K. B., W. K. Dodds, and M. E. Eberle. 2010. Retrospective analysis of fish community change during a half-century of 
landuse and streamflow changes. Journal of the North American Benthological Society 29:970-987.

Gido, K. B., J. F. Schaefer, and J. Pigg. 2004. Patterns of fish invasions in the Great Plains of North America. Biological Conservation 118:121-131.

Gladden, J. E., and L. A. Smock. 1990. Macroinvertebrate distribution and production on the floodplains of two lowland headwater streams. Freshwater Biology 24:533-545.

Gottsberger, G. 1978. Seed dispersal by fish in inundated regions of Humaita, Amazonia. Biotropica 10:170-183.

Grimm, N. B. 1988. Feeding dynamics, nitrogen budgets, and ecosystem role of a desert stream omnivore, Agosia chrysogaster (Pisces, Cyprinidae). Environmental Biology of Fishes 21:143152.

Harvey, C. J., B. J. Peterson, W. B. Bowden, A. E. Hershey, M. C. Miller, L. A. Deegan, and J. C. Finlay. 1998. Biological responses to fertilization of Oksrukuyik Creek, a tundra stream. Journal of the North American Benthological Society 17:190 209.

Hayford, B., and J. Gelhaus. 2010. The relationship between grazing, erosion and adult aquatic insects in streams in Mongolia. Mongolian Journal of Biological Sciences 8:27-39.

Heffernan, J. B., P. A. Soranno, M. J. Angilletta, L. B. Buckley, D. S. Gruner, T. H. Keitt, J. R. Kellner, J. S. Kominoski, A. V. Rocha, and J. Xiao. 2014. Macrosystems ecology: understanding ecological patterns and processes at continental scales. Frontiers in Ecology and the Environment 12:5-14.

Hijmans, R. J., S. E. Cameron, J. L. Parra, P. G. Jones, and A. Jarvis. 2005. Very high resolution interpolated climate surfaces for global land areas. International Journal of Climatology 25:1965-1978.

Holdridge, L. R. 1947. Determination of world plant formations from simple climatic data. American Association for the Advancement of Science. Science 105:367-368.

Horton, R. E. 1945. Erosional development of streams and their drainage basins; hydrophysical approach to quantitative morphology. Geological Society of America Bulletin 56:275-370.

Huryn, A. D. 1998. Ecosystem-level evidence for top-down and bottom-up control of production in a grassland stream system. Oecologia (Berlin) 115:173-183.

Huryn, A. D., and J. B. Wallace. 1987. Local geomorphology as a determinant of macrofaunal production in a mountain stream. Ecology 68:1932-1942.

Huryn, A. D., and J. B. Wallace. 2000. Life history and production of stream insects. Annual Review of Entomology 45:83-110.

Hynes, H. 1975. Edgardo Baldi Memorial Lecture. The stream and its valley. Verhandlungen der Internationalen Vereinigung für theoretische und angewandte Limnologie 19:1-15.

Ice, G. G., D. G. Neary, and P. W. Adams. 2004. Effects of wildfire on soils and watershed processes. Journal of Forestry 102:16-20.

Inoue, M., and M. Nunokawa. 2005. Spatial variation in density of stream benthic fishes in northern Hokkaido, Japan: does riparian vegetation affect fish density via food availability? Limnology 6:7-14.

Jackson, J. K., and S. G. Fisher. 1986. Secondary production, emergence, and export of aquatic insects of a Sonoran Desert stream. Ecology 67:629-638.
Junk, W. J., P. B. Bayley, and R. E. Sparks. 1989. The flood pulse concept in river-floodplain systems. Canadian Special Publication of Fisheries and Aquatic Sciences 106:110-127.

Kemp, M. J., and W. K. Dodds. 2001. Spatial and temporal patterns of nitrogen concentrations in pristine and agriculturallyinfluenced prairie streams. Biogeochemistry 53:125-141.

Knapp, A. K., and M. D. Smith. 2001. Variation among biomes in temporal dynamics of aboveground primary production. Science 291:481-484.

Kohler, T. J., J. N. Murdock, K. B. Gido, and W. K. Dodds. 2011. Nutrient loading and grazing by the minnow Phoxinus erythrogaster shift periphyton abundance and stoichiometry in mesocosms. Freshwater Biology 56:1133-1146.

Lake, P. S. 2003. Ecological effects of perturbation by drought in flowing waters. Freshwater Biology 48:1161-1172.

Langford, R. P. 1989. Fluvial-aeolian interactions. 1. Modern systems. Sedimentology 36:1023-1035.

Larson, D. M., W. K. Dodds, K. E. Jackson, M. R. Whiles, and K. R. Winders. 2013a. Ecosystem characteristics of remnant, headwater tallgrass prairie streams. Journal of Environmental Ouality 42:239-249.

Larson, D. M., B. P. Grudzinski, W. K. Dodds, M. D. Daniels, A. Skibbe, and A. Joern. 2013b. Blazing and grazing: influences of fire and bison on tallgrass prairie stream water quality. Freshwater Science 32:779-791.

Leopold, L. B. 1994. A view of the river. Harvard University Press, Cambridge, Massachusetts.

Lucas, L. K., Z. Gompert, J. R. Ott, and C. C. Nice. 2009. Geographic and genetic isolation in spring-associated Eurycea salamanders endemic to the Edwards Plateau region of Texas. Conservation Genetics 10:1309-1319.

Magilligan, F. J., and K. H. Nislow. 2005. Changes in hydrologic regime by dams. Geomorphology 71:61-78.

Malmon, D. V., S. L. Reneau, D. Katzman, A. Lavine, and J. Lyman. 2007. Suspended sediment transport in an ephemeral stream following wildfire. Journal of Geophysical Research: Earth Surface (2003-2012) 112:F02006.

Mandrak, N. E., and E. Crossman. 1992. Postglacial dispersal of freshwater fishes into Ontario. Canadian Journal of Zoology 70:2247-2259.

Matthews, W. J. 1998. Patterns in freshwater fish ecology. $2^{\text {nd }}$ printing. Kluwer Academic Press, New York.

McBride, M., W. C. Hession, and D. M. Rizzo. 2010. Riparian reforestation and channel change: how long does it take? Geomorphology 116:330-340.

McCluney, K. E., N. L. Poff, M. A. Palmer, J. H. Thorp, G. C. Poole, B. S. Williams, M. R. Williams, and J. S. Baron. 2014. Riverine macrosystems ecology: sensitivity, resistance, and resilience of whole river basins with human alterations. Frontiers in Ecology and the Environment 12:48-58.

McIntosh, R. P. 1967. Continuum concept of vegetation. Botanical Review 33:130-187.

Merritt, D. M., and E. E. Wohl. 2003. Downstream hydraulic geometry and channel adjustment during a flood along an ephemeral, arid-region drainage. Geomorphology 52:165-180.

Mims, M. C., and J. D. Olden. 2012. Life history theory predicts streamflow effects on fish assemblage response to hydrologic regimes. Ecology 93:35-45. 
Mims, M. C., J. D. Olden, Z. R. Shattuck, and N. L. Poff. 2010. Life history trait diversity of native freshwater fishes in North America. Ecology of Freshwater Fish 19:390-400.

Minshall, G. W., J. T. Brock, and J. D. Varley. 1989. Wildfires and Yellowstone stream ecosystems. BioScience 39:707-715.

Moyle, P. B., and T. Light. 1996. Biological invasions of fresh water: empirical rules and assembly theory. Biological Conservation 78:149-161.

Mulholland, P. J., A. M. Helton, G. C. Poole, R. O. Hall, S. K. Hamilton, B. J. Peterson, J. L. Tank, L. R. Ashkenas, L. W. Cooper, C. N. Dahm, W. K. Dodds, S. E. G. Findlay, S. V. Gregory, N. B. Grimm, S. L. Johnson, W. H. McDowell, J. L. Meyer, H. M. Valett, J. R. Webster, C. P. Arango, J. J. Beaulieu, M. J. Bernot, A. J. Burgin, C. L. Crenshaw, L. T. Johnson, B. R. Niederlehner, J. M. O’Brien, J. D. Potter, R. W. Sheibley, D. J. Sobota, and S. M. Thomas. 2008. Stream denitrification across biomes and its response to anthropogenic nitrate loading. Nature 452:202-205.

Murdock, J. N., K. B. Gido, W. K. Dodds, K. N. Bertrand, and M. R. Whiles. 2010. Consumer return chronology alters recovery trajectory of stream ecosystem structure and function following drought. Ecology 91:1048-1062.

Naiman, R. J., and K. H. Rogers. 1997. Large animals and system level characteristics in river corridors. BioScience 47: 521-529.

Nakamura, F., and H. Yamada. 2005. Effects of pasture development on the ecological functions of riparian forests in Hokkaido in northern Japan. Ecological Engineering 24: 539-550.

Nakano, S., and M. Murakami. 2001. Reciprocal subsidies: dynamic interdependence between terrestrial and aquatic food webs. Proceedings of the National Academv of Sciences of the United States of America 98:166-170.

Nyström, P., A. R. McIntosh, and M. J. Winterbourn. 2003. Top-down and bottom-up processes in grassland and forested streams. Oecologia (Berlin) 136:596-608.

Olden, J. D., and N. L. Poff. 2003. Redundancy and the choice of hydrologic indices for characterizing streamflow regimes. River Research and Applications 19:101-121.

Olson, D. M., E. Dinerstein, E. D. Wikramanayake, N. D. Burgess, G. V. N. Powell, E. C. Underwood, J. A. D'Amico, I. Itoua, H. E. Strand, J. C. Morrison, C. J. Loucks, T. F. Allnutt, T. H. Ricketts, Y. Kura, J. F. Lamoreux, W. W. Wettengel, P. Hedao, and K. R. Kassem. 2001. Terrestrial ecoregions of the worlds: a new map of life on Earth. BioScience 51:933-938.

Omernik, J. M. 1987. Ecoregions of the conterminous United States. Annals of the Association of American Geographers 77:118-125.

Pearson, R. G., and L. Boyero. 2009. Gradients in regional diversity of freshwater taxa. Journal of the North American Benthological Society 28:504-514.

Perkin, J. S., and K. B. Gido. 2011. Stream fragmentation thresholds for a reproductive guild of Great Plains fishes. Fisheries 36:371-383.

Poff, N. L., J. D. Allan, M. B. Bain, J. R. Karr, K. L. Prestegaard, B. D. Richter, R. E. Sparks, and J. C. Stromberg. 1997. The natural flow regime. A paradigm for river conservation and restoration. BioScience 47:769-784.

Poff, N. L., J. D. Olden, D. M. Pepin, and B. P. Bledsoe. 2006a. Placing global stream flow variability in geographic and geo- morphic contexts. River Research and Applications 22:149166.

Poff, N. L., J. D. Olden, N. K. M. Vieira, D. S. Finn, M. P. Simmons, and B. C. Kondratieff. 2006b. Functional trait niches of North American lotic insects: traits-based ecological applications in light of phylogenetic relationships. Journal of the North American Benthological Society 25:730-755.

Ponette-González, A. G., E. Marín-Spiotta, K. A. Brauman, K. A. Farley, K. C. Weathers, and K. R. Young. 2014. Hydrologic connectivity in the high-elevation tropics: heterogeneous responses to land change. BioScience 64:92-104.

Pough, F. H., R. M. Andrews, J. E. Cadle, M. L. Crump, A. H. Savitsky, and K. D. Wells. 2003. Herpetology. $3^{\text {rd }}$ edition. Prentice-Hall, Upper Saddle River, New Jersey.

Power, M. E., W. J. Matthews, and A. J. Stewart. 1985. Grazing minnows, piscivorous bass, and stream algae: dynamics of a strong interaction. Ecology 66:1448-1456.

Prentice, I. C., W. Cramer, S. P. Harrison, R. Leemans, R. A. Monserud, and A. M. Solomon. 1992. A global biome model based on plant physiology and dominance, soil properties and climate. Journal of Biogeography 19:117-134.

Raymond, P. A., J. Hartmann, R. Lauerwald, S. Sobek, C. McDonald, M. Hoover, D. Butman, R. Striegl, E. Mayorga, C. Humborg, P. Kortelainen, H. Duerr, M. Meybeck, P. Ciais, and P. Guth. 2013. Global carbon dioxide emissions from inland waters. Nature 503:355-359.

Reece, P. F., and J. S. Richardson. 2000. Benthic macroinvertebrate assemblages of coastal and continental streams and large rivers of southwestern British Columbia, Canada. $\underline{\mathrm{Hv}-}$ drobiologia 439:77-89.

Sabo, J. L., J. C. Finlay, T. Kennedy, and D. M. Post. 2010. The role of discharge variation in scaling of drainage area and food chain length in rivers. Science 330:965-967.

Saunders, W. C., and K. D. Fausch. 2007. Improved grazing management increases terrestrial invertebrate inputs that feed trout in Wyoming rangeland streams. Transactions of the American Fisheries Society 136:1216-1230.

Simon, A., W. Dickerson, and A. Heins. 2004. Suspendedsediment transport rates at the 1.5-year recurrence interval for ecoregions of the United States: transport conditions at the bankfull and effective discharge? Geomorphology 58:243-262.

Smil, V. 2011. Harvesting the biosphere: the human impact. Population and Development Review 37:613-636.

Smith, R. A., R. B. Alexander, and G. E. Schwarz. 2003. Natural background concentrations of nutrients in streams and rivers of the conterminous United States. Environmental Science and Technology 37:3039-3047.

Stagliano, D. M., and M. R. Whiles. 2002. Macroinvertebrate production and trophic structure in a tallgrass prairie headwater stream. Journal of the North American Benthological Society 21:97-113.

Stanley, E. H., D. L. Buschman, A. J. Boulton, N. B. Grimm, and S. G. Fisher. 1994. Invertebrate resistance and resilience to intermittency in a desert stream. American Midland Naturalist 131:288-300.

Staver, A. C., S. Archibald, and S. A. Levin. 2011. The global extent and determinants of savanna and forest as alternative biome states. Science 334:230-232.

Sweeney, B. W., T. L. Bott, J. K. Jackson, L. A. Kaplan, J. D. Newbold, L. J. Stanley, W. C. Hession, and R. J. Horwitz. 2004. 
Riparian deforestation, stream narrowing, and loss of stream ecosystem services. Proceedings of the National Academy of Sciences of the United States of America 101:14132-14137.

Teague, W. R., S. L. Dowhower, S. A. Baker, R. J. Ansley, U. P. Kreuter, D. M. Conover, and J. A. Waggoner. 2010. Soil and herbaceous plant responses to summer patch burns under continuous and rotational grazing. Agriculture Ecosystems and Environment 137:113-123.

Teresa, F. B., and R. D. M. Romero. 2010. Influence of the riparian zone phytophysiognomies on the longitudinal distribution of fishes: evidence from a Brazilian savanna stream. Neotropical Ichthyology 8:163-170.

Thorp, J. H., M. C. Thoms, and M. D. Delong. 2006. The riverine ecosystem synthesis: biocomplexity in river networks across space and time. River Research and Applications 22:123-147.

Trimble, S. W., and A. C. Mendel. 1995. The cow as a geomorphic agent-a critical review. Geomorphology 13:233-253.

Turner, T. F., and J. C. Trexler. 1998. Ecological and historical associations of gene flow in darters (Teleostei: Percidae). Evolution 52:1781-1801.

Van Horn, D. J., C. S. White, E. A. Martinez, C. Hernandez, J. P. Merrill, R. R. Parmenter, and C. N. Dahm. 2012. Linkages between riparian characteristics, ungulate grazing, and geomorphology and nutrient cycling in montane grassland streams. Rangeland Ecology and Management 65:475-485.

Vannote, R. L., C. W. Minshall, K. W. Cummins, J. R. Sedell, and C. E. Cushing. 1980. The river continuum concept. Canadian Journal of Fisheries and Aquatic Sciences 37:130-137.

Vidon, P., M. A. Campbell, and M. Gray. 2008. Unrestricted cattle access to streams and water quality in till landscape of the Midwest. Agricultural Water Management 95:322-330.

Wantzen, K. M. 2003. Cerrado streams-characteristics of a threatened freshwater ecosystem type on the Tertiary Shields of Central South America. Amazoniana-Limnologia et Oecologia Regionalis Systemae Fluminis Amazonas 17:481-502.

Ward, J. V., and J. A. Stanford. 1995. The serial discontinuity concept: extending the model to floodplain rivers. Regulated Rivers Research and Management 10:159-168.

Webster, J. R., P. J. Mulholland, J. L. Tank, H. M. Valett, W. K. Dodds, B. J. Peterson, W. B. Bowden, C. N. Dahm, S. Findlay, S. V. Gregory, N. B. Grimm, S. K. Hamilton, S. L. Johnson, E. Martí, W. H. McDowell, J. L. Meyer, D. D. Morrall, S. A. Thomas, and W. M. Wollheim. 2003. Factors affecting ammonium uptake in streams-an inter-biome perspective. Freshwater Biology 48:1329-1352.

Welsh, H. H., G. R. Hodgson, and N. E. Karraker. 2005. Influences of the vegetation mosaic on riparian and stream environments in a mixed forest-grassland landscape in "Mediterranean" northwestern California. Ecography 28:537-551.

Whiles, M. R., and W. K. Dodds. 2002. Relationships between stream size, suspended particles, and filter-feeding macroinvertebrates in a Great Plains drainage network. Journal of Environmental Quality 31:1589-1600.

Whiles, M. R., B. S. Goldowitz, and R. E. Charlton. 1999. Life history and production of a semi-terrestrial limnephilid caddisfly in an intermittent Platte River wetland. Iournal of the North American Benthological Society 18:533-544.

White, D. S. 1978. A revision of the nearctic Optioservus (Coleoptera: Elmidae) with descriptions of new species. Systematic Entomology 3:59-74.

Whiteman, N. K., and R. W. Sites. 2008. Aquatic insects as umbrella species for ecosystem protection in Death Valley National Park. Journal of Insect Conservation 12:499-509.

Whiting, D. P., M. R. Whiles, and M. L. Stone. 2011. Patterns of macroinvertebrate production, trophic structure, and energy flow along a tallgrass prairie stream continuum. Limnology and Oceanography 56:887-898. 